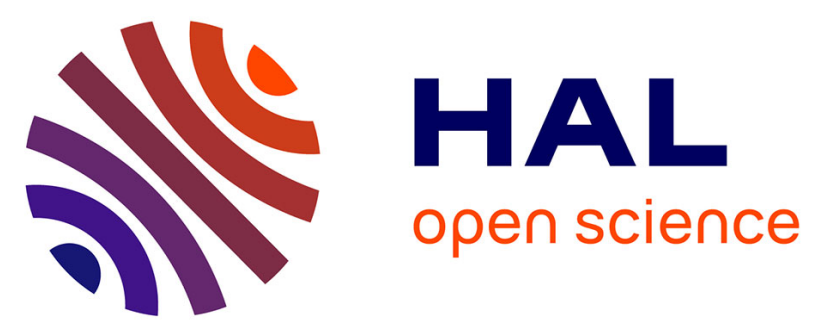

\title{
Functionalized Ruthenium Complexes: Selective "Turn-on" Detection of Biologically Relevant Anionic Species
}

\author{
Emanuela Berni, Laurent Le Henaff, Lucie Jarrige, Emeline Girard, \\ Gediminas Jonusauskas, Isabelle Gosse, Sandra Pinet
}

\section{To cite this version:}

Emanuela Berni, Laurent Le Henaff, Lucie Jarrige, Emeline Girard, Gediminas Jonusauskas, et al.. Functionalized Ruthenium Complexes: Selective "Turn-on" Detection of Biologically Relevant Anionic Species. European Journal of Organic Chemistry, 2017, 2017 (25), pp.3620-3630. 10.1002/ejoc.201700586 . hal-01569750

\section{HAL Id: hal-01569750 \\ https://hal.science/hal-01569750}

Submitted on 27 Jul 2017

HAL is a multi-disciplinary open access archive for the deposit and dissemination of scientific research documents, whether they are published or not. The documents may come from teaching and research institutions in France or abroad, or from public or private research centers.
L'archive ouverte pluridisciplinaire HAL, est destinée au dépôt et à la diffusion de documents scientifiques de niveau recherche, publiés ou non, émanant des établissements d'enseignement et de recherche français ou étrangers, des laboratoires publics ou privés.

\section{(C)(1) (2)}

Distributed under a Creative Commons Attribution - ShareAlikel 4.0 International 


\title{
Functionalized Ruthenium Complexes: Selective "Turn-on" Detection of Biologically Relevant Anionic Species
}

\author{
Emanuela Berni, ${ }^{[a, b]}{ }^{b}$ aurent Le Henaff, ${ }^{[a, b]}$ Lucie Jarrige, ${ }^{[a, b]}$ Emeline Girard, ${ }^{[a, b]}$ \\ Gediminas Jonusauskas, ${ }^{[c]}$ Isabelle Gosse, ${ }^{*[a, b]}$ and Sandra Pinet ${ }^{*[a, b]}$
}

\begin{abstract}
To study the effect of the structure of 3,3'-modified bipyridyl ruthenium complexes on their ability to recognize organic anions, various ruthenium complexes have been prepared. The binding functions and large-sized modified bipyridyl ligand turned out to be essential for selectivity in acetonitrile. The selectivity for dicarboxylates or phosphates can be switched by using guanidinium- or ammonium-functionalized probes. One of these probes turned out to be selective towards glutamate over aspartate and $\gamma$-aminobutyric acid (GABA). Another was selective towards adenosine $5^{\prime}$-triphosphate (ATP)
\end{abstract}

over adenosine $5^{\prime}$-diphosphate (ADP), pyrophosphate (PPi), adenosine $5^{\prime}$-monophosphate (AMP), and orthophosphate (Pi). In both cases, the binding was attributed to coulombic interactions and hydrogen bonding. $\pi$-stacking interactions also occurred with nucleotides. Replacing ammonium by zinc-dipicolylamine units made possible the recognition of phosphorylated species in buffered aqueous systems. To our delight, this probe showed selectivity for ADP over ATP and we proved that the selectivity was partly due to substitution at the 3- and 3'-positions of the ligand.

\section{Introduction}

Anions play fundamental roles in a wide range of chemical, biological, and environmental processes. For instance, phosphates and nucleotides such as adenosine 5'-triphosphate (ATP), adenosine $5^{\prime}$-diphosphate (ADP), and adenosine $5^{\prime}$ monophosphate (AMP) are involved in energy storage, ionchannel regulation, ${ }^{[1]}$ and phosphorylation. ${ }^{[2]}$ During phosphorylation, kinases transfer the terminal phosphate from ATP onto a protein, a sugar, or a lipid. In parallel, ADP is released. The phosphorylation of proteins, by inducing structural modifications, switches on or off their enzymatic activity and in this way regulates many essential biological processes. ${ }^{[3]} \mathrm{A}$ way to measure the activity of enzymes that catalyze metabolic processes leading to the production of ADP would be to detect ADP selectively.

The development of luminescent chemosensors for halides, carboxylates, and inorganic and organic phosphates, such as nucleotides, has received substantial attention in the last few decades. ${ }^{[4]}$ Many examples of fluorescent probes with metallic receptors, mainly zinc, ${ }^{[5]}$ copper, $_{,}^{[6]}$ and more recently aluminium, ${ }^{[7]}$ have been successfully used to detect selectively pyro-

[a] ISM, UMR 5255 CNRS, Univ. Bordeaux,

351 Cours de la libération, 33400 Talence, France

E-mail: gosse@enscbp.fr pinet@enscbp.fr

http://www.ism.u-bordeaux1.fr/spip.php?auteur119\&lang=en

[b] ENSCBP, Bordeaux INP,

16 Avenue Pey Berland, 33607 Pessac, France

[c] LOMA, UMR 5798, CNRS, Univ. Bordeaux,

351 Cours de la libération, 33400 Talence, France phosphate (PPi). Luminescent probes able to recognize preferentially ATP over PPi and other adenosine phosphates have also been abundantly described. ${ }^{[8]}$ In general, the observed selectivity is ascribed to stronger electrostatic interactions between the probe and the triphosphate. Conversely, examples of selective chemical probes for AMP or ADP are scarce. ${ }^{[9]}$ In the case of $A D P$, binding experiments with these sensors were conducted either in organic solvent ${ }^{[9 \mathrm{~g}, 9 \mathrm{k}]}$ or in hydroorganic medium. ${ }^{[9 \mathrm{~b}-9 \mathrm{~d}]}$ The bindings of ADP and PPI were otherwise compared in only one case. ${ }^{[9 \mathrm{~d}]}$ Thus, the elaboration of new probes able to interact preferentially with organic anions, in particular with ADP, is still a challenge. Ideally, the luminescence intensity of such probes should increase upon the binding of guests.

Having this in mind, we developed a straightforward procedure for the synthesis of flexible probes for anion recognition (Figure 1). We explored the structure-binding relationship in acetonitrile to determine both the interactions involved and the parameters that influence the binding and selectivity. Then, we introduced the zinc dipicolylamine group for the recognition of phosphorylated species in aqueous systems.

The chosen luminophore was a tris-bipyridyl ruthenium complex, a luminescent compound with absorption and emission spectra in the visible region. ${ }^{[4,, 10]}$ Many bipyridyl ruthenium(II) luminescent probes for the detection of small inorganic anions have been described. ${ }^{[4 \mathrm{~d}-4 \mathrm{f}]}$ Usually, the recognition is achieved by the functionalization of one of the bipyridyl ligands, most of the time at the $4,4^{\prime}$-positions. ${ }^{[4 e, f, 11]}$ In this work, one of the bipyridines was modified at the 3,3'-positions through amide subunits. Indeed, in a preliminary study we saw that even if the quantum yield of the 3,3'-bipyridyl-modified ruthenium(II) complex is lower than that of its $4,4^{\prime}$-analogue, the increase in luminescence, observed upon the addition of different species, 


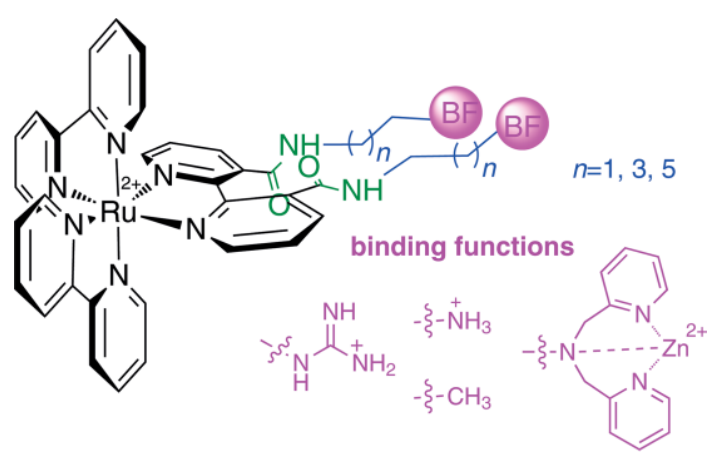

Figure 1. Structure of the synthesized 3,3'-bipyridyl-modified Rull probes.

is often greater. ${ }^{[12]}$ Three different binding functions were selected: Guanidinium and ammonium groups, both well-known to interact strongly with oxo anions through hydrogen bonds and charge interactions, ${ }^{[4 b, 4 f, 13]}$ and a zinc(II) dipicolylamine complex, able to bind anions in aqueous medium. Various chain lengths were introduced between the amides and terminal binding sites to study the impact of the size of the molecular probe on both the recognition and selectivity. Finally, an analogous compound without a terminal binding site was also prepared to determine the role of amides in the recognition process.

\section{Results and Discussion}

\section{Probe Design and Synthesis}

To access the ruthenium probes we developed a rapid and easy synthesis starting from binicotinic acid, prepared on a gram scale from 1,10-phenanthroline. ${ }^{[14]}$ The reaction of binicotinic acid with 2-(n-aminoalkyl)-1,3-diBoc-guanidines in the presence of EDCI and DMAP, followed by acidic deprotection of the guanidinium functions ( $n=2,4$, and 6) led to guanidinium-functionalized ligands $L_{1} / L_{3}$ in yields varying from 57 to $71 \%$ (Scheme 1). Other ligands were obtained by using the same strategy; $\mathbf{L}_{\mathbf{4}}$ and $\mathbf{L}_{\mathbf{5}}$, from commercially available (aminoalkyl)carbamates, in yields of 48 and $84 \%$, respectively, and $\mathbf{L}_{\mathbf{6}}$, from hexylamine, in $77 \%$ yield. Heating 1 equivalent of the appropriate ligand $\mathbf{L}_{\boldsymbol{i}}$ at reflux with cis-[(bipy $\left.)_{2} \mathrm{RuCl}_{2}\right] \cdot 2 \mathrm{H}_{2} \mathrm{O}$ led to the ruthenium(II) complexes. After ion exchange, $\mathbf{R} \mathbf{u}_{\mathbf{1}}-\mathbf{R} \mathbf{u}_{\mathbf{6}}$ were recovered in good yields (52-79\%) as their hexafluorophosphate salts. They were obtained pure, except $\mathbf{R} \mathbf{u}_{\mathbf{4}}$, recovered with $90 \%$ purity. In fact, the high solubility of $\mathbf{R} \mathbf{u}_{\mathbf{4}}$ in water prevented us from removing the excess of ammonium hexafluorophosphate used for the anion exchange. The amount of remaining $\mathrm{NH}_{4} \mathrm{PF}_{6}$ was estimated by ${ }^{1} \mathrm{H}$ and ${ }^{19} \mathrm{~F}$ NMR experiments using (R)-(-)-1-(9-anthryl)-2,2,2-trifluoroethanol as internal reference. The elemental analysis of ruthenium complexes $\mathbf{R} \mathbf{u}_{\mathbf{1}}-\mathbf{R} \mathbf{u}_{\mathbf{5}}$ showed the presence of four hexafluorophosphate anions, proving the protonation of both guanidines and amines in the solid state. Access to zinc(II) dipicolylamine analogue $\mathbf{R} \mathbf{u}_{\mathbf{7}}$ was achieved by classical reductive amination of $\mathbf{R} \mathbf{u}_{\mathbf{5}}$ in the presence of 2-pyridinecarbaldehyde, followed by the addition of 2 equivalents of zinc dichloride. The water-soluble probe $\mathbf{R} \mathbf{u}_{\mathbf{7}}$ was obtained pure in $94 \%$ yield.

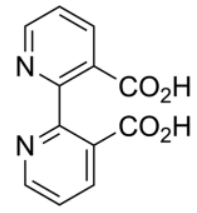<smiles>[R]C[Y10]([H])([H])CNOc1cccnc1-c1ncccc1ONCC</smiles><smiles></smiles>

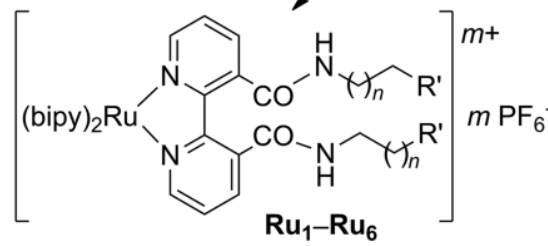

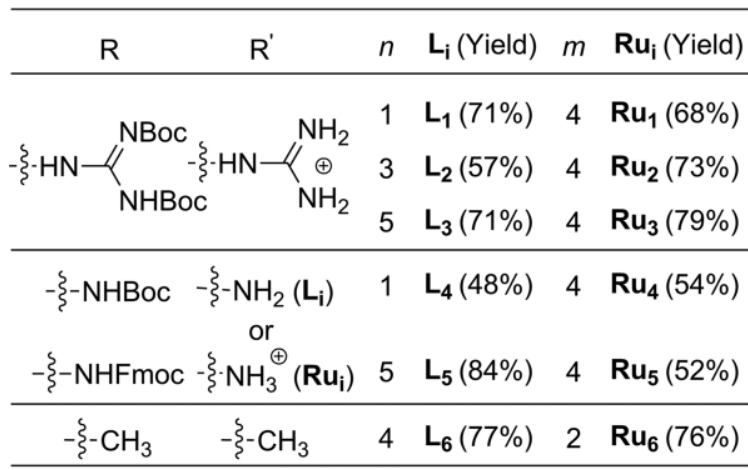

$$
\mathbf{R u}_{5} \underset{95 \%}{\stackrel{\mathrm{e}, \mathrm{f}}{\longrightarrow}}\left[\begin{array}{c}
\text { (bipy) }{ }_{2} \mathrm{RuL}_{7} \\
\mathbf{R u _ { 7 }}
\end{array}\right]^{2+} 2 \mathrm{PF}_{6}^{-}, 4 \mathrm{Cl}^{-}
$$

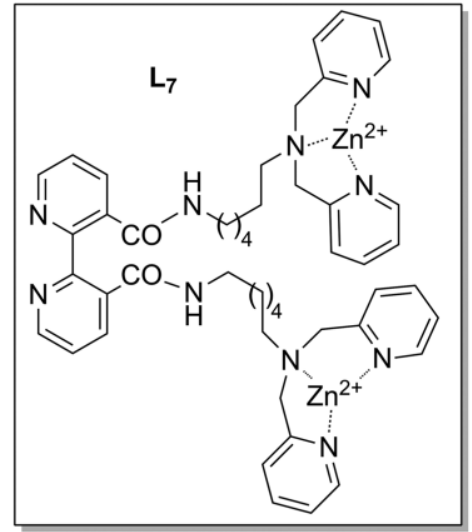

a) $\mathrm{H}_{2} \mathrm{~N} \Upsilon_{M_{n}}^{\mathrm{R}}$, EDCI, DMAP, DCM

b) $\mathrm{HCl}, \mathrm{DCM}$ or $\mathrm{AcCl} \mathrm{MeOH}$ or piperidine, $\mathrm{DCM}$

c) cis- $\mathrm{Ru}(\text { bipy })_{2} \mathrm{Cl}_{2},(9: 1) \mathrm{EtOH}-\mathrm{H}_{2} \mathrm{O}, \Delta$; d) $\mathrm{NH}_{4} \mathrm{PF}_{6}, \mathrm{H}_{2} \mathrm{O}$

e) $\mathrm{NaBH}(\mathrm{OAc})_{3}, \mathrm{Pr}_{2} \mathrm{NH}, \mathrm{DCM}$; f) $\mathrm{ZnCl}_{2}, \mathrm{CH}_{3} \mathrm{CN}$

Scheme 1. Synthesis of 3,3-functionalized $\mathbf{R} \mathbf{u}_{\mathbf{1 - 6}}$ complexes.

\section{Photoluminescence Characterization of the Ruthenium Complexes}

As shown in Table 1, in acetonitrile, all the synthesized trisbipyridyl ruthenium complexes show two characteristic absorption bands at about 287 and $440 \mathrm{~nm}$ corresponding to ligandcenter (LC) and metal-to-ligand charge-transfer (MLCT) transitions, respectively. Owing to the electron-withdrawing nature 
Table 1. Spectroscopic characterization of the Ru complexes at $25^{\circ} \mathrm{C}$ in acetonitrile or in $25 \mathrm{~mm}$ Hepes buffer (pH 7.4 , marked by ${ }^{* *}$ ).

\begin{tabular}{|c|c|c|c|c|c|c|c|c|}
\hline \multirow[t]{2}{*}{ Complex } & \multicolumn{2}{|c|}{ Absorbance } & \multirow[b]{2}{*}{$\lambda_{\max }[\mathrm{nm}]^{[\mathrm{aa}]}$} & \multirow[b]{2}{*}{$\Phi[\%]^{[c]}$} & \multicolumn{3}{|c|}{ Emission } & \multirow[b]{2}{*}{$\tau_{\mathrm{o}}[\mu \mathrm{s}]^{[f]}$} \\
\hline & $\lambda_{\max }[\mathrm{nm}]^{[\mathrm{a}]}$ & $\varepsilon\left[\mathrm{M}^{-1} \mathrm{~cm}^{-1}\right]^{[\mathrm{b}]}$ & & & $\tau[\mathrm{ns}]^{[\mathrm{d}]}$ & $k_{\mathrm{r}}\left[\mathrm{s}^{-1}\right]^{[\mathrm{e}]}$ & $k_{\mathrm{nr}}\left[\mathrm{s}^{-1}\right]^{[\mathrm{e}]}$ & \\
\hline \multirow{2}{*}[\mathrm{Ru}(\text{bipy})_{3}]{$^{2+}$} & $287(\mathrm{LC})^{[\mathrm{g}]}$ & $79800^{[\mathrm{g}]}$ & $609^{[g]}$ & $6.2^{[\mathrm{h}]}$ & $855^{[\mathrm{h}]}$ & $7.7 \times 10^{4[\mathrm{~h}]}$ & $4.8 \times 10^{5[\mathrm{~h}]}$ & 13.0 \\
\hline & $450(\mathrm{MLCT})^{[\mathrm{gl}]}$ & $14300^{[g]}$ & & & & & & \\
\hline \multirow[t]{2}{*}{$\mathbf{R u}_{1}$} & 287 (LC) & 57700 & 712 & 2.2 & 88 & $2.34 \times 10^{5}$ & $1.11 \times 10^{7}$ & 4.27 \\
\hline & 434 (MLCT) & 8700 & & & 145 & & & \\
\hline \multirow[t]{2}{*}{$\mathbf{R u}_{2}$} & $287(\mathrm{LC})$ & 62600 & 713 & 2.2 & 56 & $2.37 \times 10^{5}$ & $1.76 \times 10^{7}$ & 4.21 \\
\hline & 445 (MLCT) & 10200 & & & 140 & & & \\
\hline \multirow[t]{2}{*}{$\mathbf{R u}_{3}$} & $288(\mathrm{LC})$ & 72000 & 712 & 2.3 & 53 & $2.38 \times 10^{5}$ & $1.86 \times 10^{7}$ & 4.21 \\
\hline & 447 (MLCT) & 11500 & & & 150 & & & \\
\hline \multirow[t]{2}{*}{$\mathbf{R u}_{4}$} & $288(\mathrm{LC})$ & 44000 & 701 & 2.4 & 93 & $2.06 \times 10^{5}$ & $1.05 \times 10^{7}$ & 4.86 \\
\hline & 451 (MLCT) & 7300 & & & 200 & & & \\
\hline \multirow[t]{2}{*}{$\mathbf{R u}_{5}$} & $287(\mathrm{LC})$ & 47300 & 712 & 2.4 & 44 & $2.83 \times 10^{5}$ & $2.24 \times 10^{7}$ & 3.54 \\
\hline & 446 (MLCT) & 7300 & & & 170 & & & \\
\hline \multirow[t]{2}{*}{$\mathbf{R u}_{6}$} & $286(\mathrm{LC})$ & 50700 & 698 & 1.9 & 40 & $1.68 \times 10^{5}$ & $2.48 \times 10^{7}$ & 5.95 \\
\hline & 447 (MLCT) & 10600 & & & 208 & & & \\
\hline \multirow[t]{2}{*}{$\mathbf{R u} \mathbf{u}_{7}$} & $286^{*}(\mathrm{LC})$ & $43100^{*}$ & $734^{*}$ & $2.0^{*}$ & $29^{*}$ & $1.87 \times 10^{5 *}$ & $3.43 \times 10^{7 *}$ & $5.34 \times 10^{-6 *}$ \\
\hline & $433^{*}(\mathrm{MLCT})$ & $8300^{*}$ & & & $178^{*}$ & & & \\
\hline
\end{tabular}

[a] $\lambda_{\max }$ of absorption and emission. [b] Molar extinction coefficient. [c] Fluorescence quantum yield ( $\left.\pm 10 \%\right)$ determined at $25^{\circ} \mathrm{C}$ for a $10^{-5} \mathrm{M}$ solution of [Ru"] in degassed $\mathrm{CH}_{3} \mathrm{CN}$. [d] Luminescence lifetime $( \pm 10 \%)$ determined by using time-correlated single-photon counting (TCSPC). [e] Radiative ( $\left.k_{\mathrm{r}}\right)$ and nonradiative $\left(k_{n r}\right)$ decay rates. [f] Radiative lifetime. [g] From ref. ${ }^{[15]}[\mathrm{h}]$ From ref. ${ }^{[19]}$

of the amide substituents, which leads to lower MLCT transition energies, the MLCT absorption band is blueshifted with respect to $\left[\mathrm{Ru}(\text { bipy })_{3}\right]^{2+}\left(\lambda_{\max }=450 \mathrm{~nm}\right) .^{[15]}$

The $\mathbf{R} \mathbf{u}_{\boldsymbol{i}}$ complexes display emission spectra with a single red-orange MLCT emission band at around $710 \mathrm{~nm}, 100 \mathrm{~nm}$ redshifted with respect to the band of $\left[\mathrm{Ru}(\mathrm{bipy})_{3}\right]\left(\mathrm{PF}_{6}\right)_{2}\left(\lambda_{\max }=\right.$ $612 \mathrm{~nm}$ ). In Hepes buffered solution, this shift is even more important (for $\mathbf{R} \mathbf{u}_{\mathbf{7}}, 734 \mathrm{~nm}$ in aqueous medium). Such a phenomenon has already been observed in ruthenium complexes functionalized with amide or ester groups. ${ }^{[14-16]}$ The quantum yields of all the 3,3'-functionalized complexes (1.9$2.4 \%)$ are much lower than that of the $\left[\mathrm{Ru}(\text { bipy })_{3}\right]^{2+}$ standard ( $\Phi=6.2 \%$ ). This can be explained by the ligand distortion in the $3,3^{\prime}$-modified ruthenium complexes that disfavors charge transfer between the metal center and the ligands. It is noteworthy that the 3,3'-modified ruthenium complexes exhibit a biexponential decay of the luminescence intensity. A short decay time (29-93 ns) and a longer one (140-208 ns) were determined. It is clear by centesimal analysis that these biexponential decay times do not derive from the presence of a luminescent impurity in the synthesized ruthenium complexes. According to the literature, biexponential decay times have already been found in the case of tris-bipyridyl ruthenium complexes. ${ }^{[17]}$ The authors reported that the observed biexponential decay may arise from the existence of two blocked conformers. Indeed, the relative rigidity of the amide moieties may prevent the conformers from interchanging within the lifetime of the excited state. In the present case, cis/trans amide isomers coexist in solution, as proved by the ${ }^{1} \mathrm{H}$ NMR spectra of these ruthenium complexes (the presence of two multiplets corresponding to the methylene at the $\alpha$ position with respect to the amide functions). The nonradiative decay rates increase with the linker length and, as expected, they are especially low for the most rigid probes, in other words, those with the shortest linker $\left(\mathbf{R} \mathbf{u}_{\mathbf{1}}\right.$ and $\left.\mathbf{R} \mathbf{u}_{\mathbf{4}}\right)^{\left[{ }^{[18]}\right.}$

\section{Anion Sensing}

\section{General Behavior of Probes Upon Addition of Anions}

The binding of anions of interest, such as dicarboxylates and phosphate derivatives, by these probes was studied by UV/Vis and luminescence spectroscopy. The complexation of more simple anions, such as chloride or monocarboxylate anions, was also tested (Figure 2).

Studied carboxylates

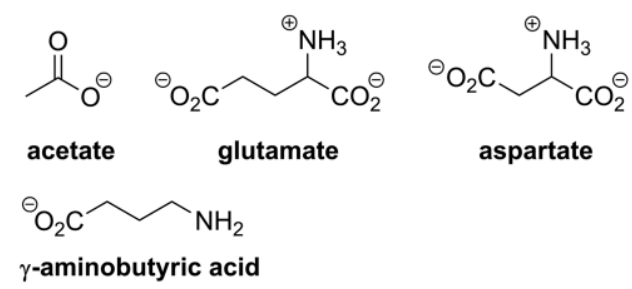

Studied phosphates

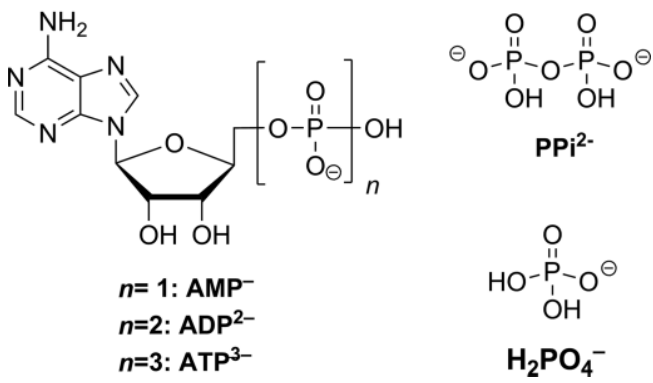

Figure 2. Structures of the studied anions.

The addition of the anions to solutions of $\mathbf{R} \mathbf{u}_{i}$ in acetonitrile did not induce any change in the absorption spectra. In the presence of chloride or acetate anions, the $\mathbf{R} \mathbf{u}_{\boldsymbol{i}}$ emission spectra were not or only very slightly affected. In contrast, the addition 
of other species to solutions of $\mathbf{R} \mathbf{u}_{\boldsymbol{i}}$ probes resulted in an increase in the luminescence intensity accompanied by a concomitant hypsochromic shift of the maximum emission wavelength $\lambda_{\text {max }}$.

This increase in luminescence intensity is consistent with the enhancement of the quantum yields of the probes measured in the presence of ions such as glutamate or dihydrogen phosphate (see Table A in the Supporting Information). As expected, regarding the non-modified $\left[\mathrm{Ru}(\text { bipy })_{3}\right]^{2+}$ complex, no changes in the emission spectra were observed upon the addition of anions. The evolution of the $\mathbf{R} \mathbf{u}_{\mathbf{5}}$ emission spectrum upon successive additions of dihydrogen phosphate is shown as an example in Figure 3. The emission enhancement can be ascribed to an increase in receptor rigidity, caused by interactions with the anions, which diminishes the potential pathways of vibrational and rotational nonradiative decay modes. To determine the influence of anions on the decay rates and decay times of the probes, we also measured them in the presence of glutamate and dihydrogen phosphate. The nonradiative decay rates decreased (except for the most rigid probe $\mathbf{R} \mathbf{u}_{\mathbf{1}}$ ), whereas the radiative decay rates showed a two- to three-fold increase in the presence of anions.

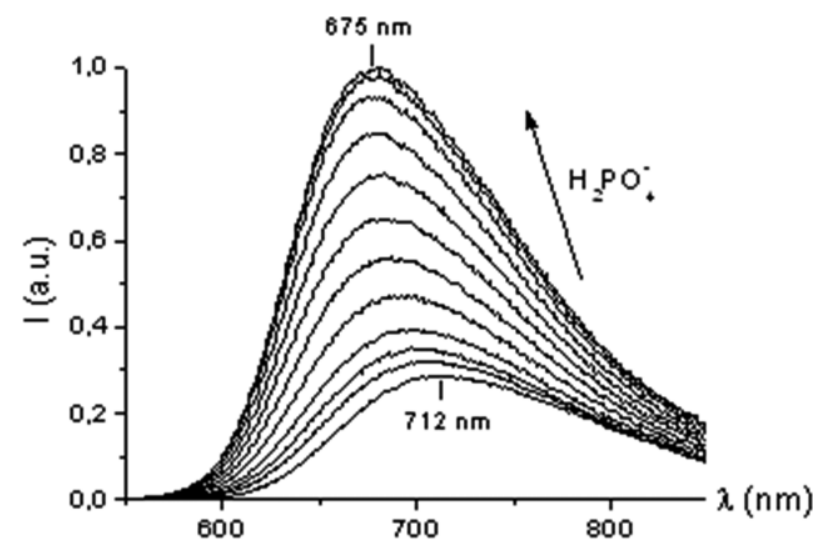

Figure 3. Fluorescence emission spectra of $\mathbf{R} \mathbf{u}_{\mathbf{5}}$ in the presence of increasing amounts of $\left(\mathrm{NBu}_{4}\right)_{2} \mathrm{H}_{2} \mathrm{PO}_{4}\left(\mathrm{H}_{2} \mathrm{PO}_{4}^{-} / \mathbf{R u}_{5}\right.$ molar ratio: $\left.0-2\right)$ in $\mathrm{CH}_{3} \mathrm{CN}$ at $25{ }^{\circ} \mathrm{C}$.
Concerning the decay times, as for the complexes $\mathbf{R} \mathbf{u}_{\boldsymbol{i}}$ alone, a biexponential decay was found when the probes interact either with glutamate or dihydrogen phosphate (see Table A in the Supporting Information). This observation suggests that the anions interact with the amide groups. Indeed, the MLCT $d \pi^{*}$ state has the electron formally residing on the bipyridine ligand, and this configuration is presumably less favorable when a negatively charged guest binds to the amide of the bipyridine. ${ }^{[16,17,20]}$ To verify the existence of interactions between amide subunits and anions, luminescence studies were carried out with the analogous probe $\mathbf{R u}_{\mathbf{6}}$, characterized by a $3,3^{\prime}$-bishexylamide modified ligand.

As for $\mathbf{R} \mathbf{u}_{\mathbf{3}}$ and $\mathbf{R} \mathbf{u}_{\mathbf{5}}$, a hypsochromic shift and an increase in the luminescence intensity were observed when $\mathrm{H}_{2} \mathrm{PO}_{4}^{-}$was added to a solution of $\mathbf{R} \mathbf{u}_{\mathbf{6}}$ in acetonitrile. Nevertheless the modification of the luminescence response is not as significant (see Figure S1 in the Supporting Information). These results show that the amide functions are implicated in the recognition event. To better identify the interactions involved we also performed ${ }^{1} \mathrm{H}$ NMR studies in deuteriated acetonitrile. The spectra of probes $\mathbf{R} \mathbf{u}_{\mathbf{3}}$ and $\mathbf{R} \mathbf{u}_{\mathbf{5}}$ in the presence of increasing amounts of either glutamate or dihydrogen phosphate were recorded. The ${ }^{1} \mathrm{H}$ NMR spectra of $\mathbf{R} \mathbf{u}_{\mathbf{3}}$ upon sequential additions of glutamate are shown as an example in Figure 4 (aromatic region) and in Figure S2 in the Supporting Information (whole ${ }^{1} \mathrm{H}$ NMR spectra). Addition of the anion leads to downfield shifts of the amide and guanidinium $\mathrm{NH}$ protons. More interestingly, the 4- $\mathrm{H}$ and $4^{\prime}-\mathrm{H}$ aromatic protons of the modified bipyridyl ligand $\mathbf{L}_{\mathbf{3}}$ as well as methylene protons linked to the amide functions are also shifted as the amount of glutamate in the solution increases. Similar results were obtained when dihydrogen phosphate was added to a solution of probe $\mathbf{R} \mathbf{u}_{\mathbf{5}}$. Nevertheless, in this case, the signals corresponding to the methylene groups were not affected by the presence of the guest (see Figure S3 in the Supporting Information). These results confirm that both amides and terminal functions are implicated in the recognition process, mainly through the formation of hydrogen bonds and electrostatic interactions with the anions.
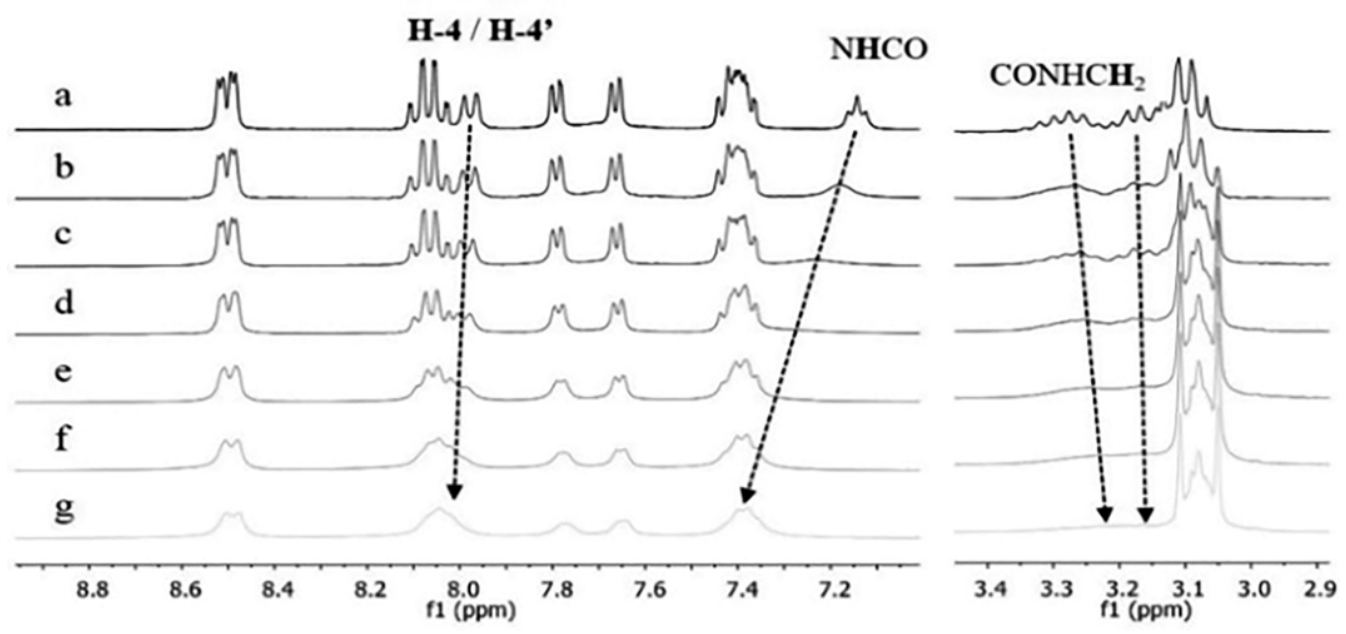

Figure 4. Evolution of the ${ }^{1} \mathrm{H}$ NMR spectra of $\mathbf{R u}_{\mathbf{3}}$ in the absence (a) and in the presence of increasing amounts of tetrabutylammonium glutamate: (b) 0.1 equiv., (c) 0.2 equiv., (d) 0.3 equiv., (e) 0.4 equiv., (f) 0.5 equiv., and (g) 0.6 equiv. The spectra were recorded in $\mathrm{CD}_{3} \mathrm{CN}$ at $25^{\circ} \mathrm{C}$. 


\section{Alkyl Spacer Length Effect and Selectivity in the Case of Guanidinium-Functionalized Bipyridyl Ruthenium Complexes}

Acetate and chloride anions did not induce any change in $\mathbf{R} \mathbf{u}_{\mathbf{3}}$ photoluminescence. The complex $\mathbf{R} \mathbf{u}_{\mathbf{3}}$ recognizes dihydrogen phosphate and dicarboxylates such as glutamate and aspartate, but also $\gamma$-aminobutyric acid (GABA; Figure $5 \mathrm{a}$ ). The titration curve recorded with GABA suggests that the amine function and/or the alkyl chain of the target interact with the binding site of $\mathbf{R} \mathbf{u}_{\mathbf{3}}$, because acetate is not recognized at all. Titrations with sulfate, succinate, and glutarate were also carried out (see Figure S4 in the Supporting Information). Among all the tested anions, glutamate is the one that induces the most significant changes in luminescence emission intensity (Figure 5a).

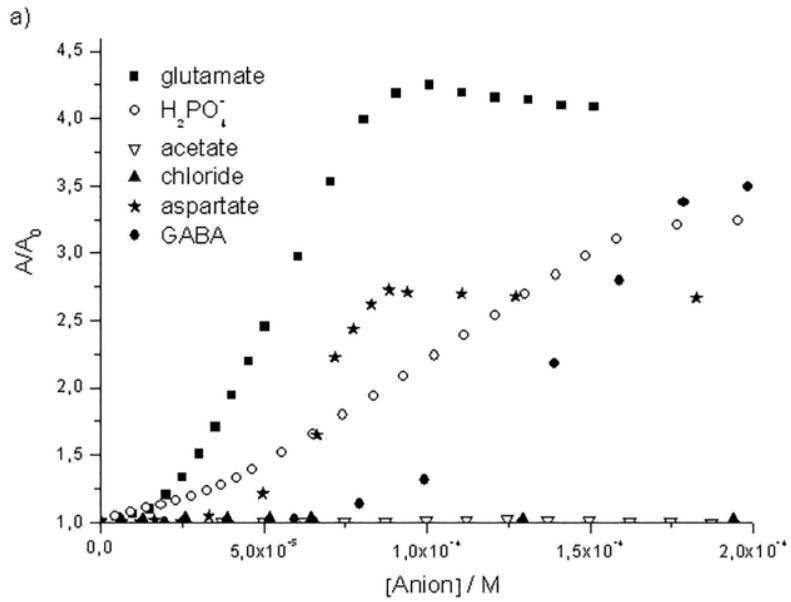

b)

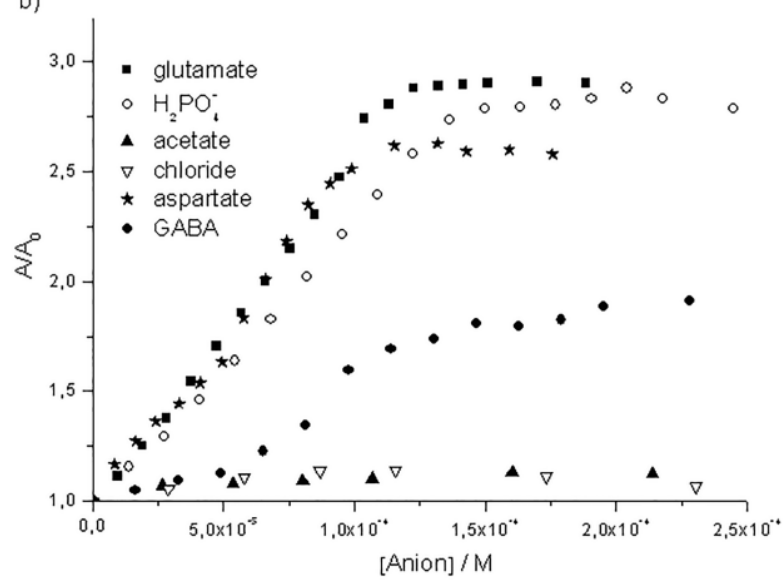

Figure 5. Relative luminescence areas of a) a $5 \times 10^{-5} \mathrm{M}$ solution of $\mathbf{R} \mathbf{u}_{\mathbf{3}}$ and b) a $5 \times 10^{-6} \mathrm{M}$ solution of $\mathbf{R} \mathbf{u}_{\mathbf{1}}$ as a function of concentration of the anions in acetonitrile $\left(\lambda_{\text {exc }}=490 \mathrm{~nm}, 25^{\circ} \mathrm{C}\right.$ ).

For comparison with $\mathbf{R} \mathbf{u}_{\mathbf{3}}$, luminescence studies were also carried out with the $\mathbf{R} \mathbf{u}_{\mathbf{1}}$ and $\mathbf{R} \mathbf{u}_{\mathbf{2}}$ complexes to study the effect of the alkyl chain length and thus the effect of host size on anion recognition. $\mathbf{R} \mathbf{u}_{\mathbf{1}}$ and $\mathbf{R} \mathbf{u}_{\mathbf{2}}$ gave similar results. As an example, Figure $5 \mathrm{~b}$ shows the titration curves of $\mathbf{R} \mathbf{u}_{\mathbf{1}}$ upon the addition of various anions: Similar responses were observed for glutamate, aspartate, and dihydrogen phosphate. Moreover, $\mathbf{R} \mathbf{u}_{\mathbf{1}}$ detects very slightly acetate and chloride, which was not observed with $\mathbf{R} \mathbf{u}_{\mathbf{3}}$. As a consequence, of the complexes studied herein, the use of the hexyl spacer provides the most efficient probe in terms of selectivity. Hence, only the results obtained with probes incorporating a hexyl spacer will be presented below.

The method of continuous variation (Job's plots) was used to characterize the $\mathbf{R u}_{\mathbf{3}}$-anion complexes and determine their stoichiometries (see Figure S8a,b in the Supporting Information). The curves indicate that $\mathbf{R} \mathbf{u}_{\mathbf{3}}$ forms complexes with $\mathbf{1 : 2}$ and 1:4 stoichiometries in the presence of glutamate and dihydrogen phosphate, respectively. The association constants of $\mathbf{R} \mathbf{u}_{\mathbf{3}}$ with glutamate $\left(\log K_{1: 2}=13.06\right)$ and dihydrogen phosphate ( $\log K_{1: 4}=18.02$ ) were determined by using HypSpec ${ }^{\oplus}$ [21] $^{[2}$ These stoichiometries are consistent with both the 4+ charge of the probes and the number of hexafluorophosphate anions that can be exchanged during the addition of guests. Most probably, only the replacement of the $\mathrm{PF}_{6}{ }^{-}$ions close to the binding functions impacts the variation in luminescence intensity. As can be seen in Figure 5a, the first added carboxylate anions did not induce noticeable variation in the luminescence intensity, which indicates that the first $\mathrm{PF}_{6}{ }^{-}$anions displaced are those interacting with the ruthenium center.

\section{Effect of the Terminal Binding Functions}

Guanidinium functions have planar structures more appropriate for interacting with carboxylates than tetrahedral ammonium ions. ${ }^{[4,13,16]}$ Thus, our idea was to modify the selectivity of such probes by replacing the terminal guanidinium moieties by ammoniums (probes $\mathbf{R} \mathbf{u}_{\mathbf{4}}$ and $\mathbf{R} \mathbf{u}_{\mathbf{5}}$ ).

As already mentioned, these ammonium-functionalized complexes present the same photophysical characteristics as the guanidinium-functionalized analogues (emission spectra with a single red-orange MLCT emission band at ca. $\lambda_{\max }=712 \mathrm{~nm}$, $100 \mathrm{~nm}$ redshifted with respect to the band for $\left[\mathrm{Ru}(\text { bipy })_{3}\right] \mathrm{PF}_{6}$ and also an attenuated luminescence efficiency). Chloride and acetate anions were not detected by the ammonium-functionalized probe $\mathbf{R} \mathbf{u}_{\mathbf{5}}$, whereas responses were obtained in the presence of dihydrogen phosphate and dicarboxylates (Figure 6).

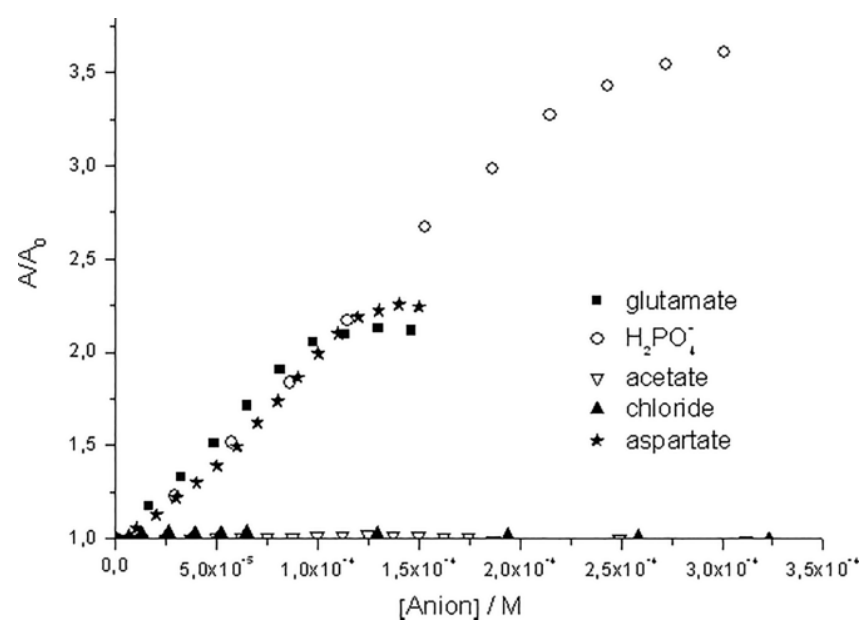

Figure 6. Relative luminescence areas of a $5 \times 10^{-5} \mathrm{M}$ solution of $\mathbf{R u}_{\mathbf{5}}$ in acetonitrile as a function of concentration of the anions $\left(\lambda_{\text {exc }}=490 \mathrm{~nm}, 25^{\circ} \mathrm{C}\right)$. 
A 1:2 stoichiometry was found for the $\mathbf{R} \mathbf{u}_{\mathbf{5}}$-glutamate complex (see Figure $\mathrm{S} 8 \mathrm{c}$ in the Supporting Information) as well as a lower binding constant $\left(\log K_{1: 2}=1159\right)$, which indicates that glutamate interacts less strongly with ammonium functions than with guanidinium. $\mathbf{R} \mathbf{u}_{\mathbf{5}}$ recognizes dihydrogen phosphate in the same way as $\mathbf{R u}_{\mathbf{3}}$ (1:4 stoichiometry and $\log K_{1: 4}=18.08$; see Figure S8d in the Supporting Information). Nevertheless, for equivalent stability constants, the quantum yield of $\mathbf{R} \mathbf{u}_{\mathbf{5}}$ in the presence of $\mathrm{H}_{2} \mathrm{PO}_{4}^{-}(\Phi=9.3)$ is higher than that measured in the case of $\mathbf{R u}_{\mathbf{3}}(\Phi=7.8$; see Table $\mathrm{A}$ in the Supporting Information). As a consequence, the ammonium-functionalized probe is more sensitive towards phosphate ions than the guanidinium. This sensitivity encouraged us to study the binding ability of $\mathbf{R} \mathbf{u}_{\mathbf{5}}$ with phosphate anions of biological interest, namely ATP, ADP, and AMP.

\section{Application to the Detection of Important Anions}

The luminescence intensity of $\mathbf{R} \mathbf{u}_{\mathbf{5}}$ was recorded upon the addition of adenosine tri-, di-, and monophosphate, PPi, and dihydrogen phosphate anions (Figure 7). Although AMP and $\mathrm{H}_{2} \mathrm{PO}_{4}^{-}$have the same charge, their titration curves are different. This difference can be ascribed to possible $\pi$-stacking interactions between the adenine base and the $\mathbf{R} \mathbf{u}_{\mathbf{5}}$ bipyridine ligands. To verify this hypothesis, titration curves with AMP and $\mathrm{H}_{2} \mathrm{PO}_{4}^{-}$were recorded with $\left[\mathrm{Ru}(\text { bipy })_{3}\right]^{2+}$ as the probe. In the presence of dihydrogen phosphate, the luminescence of $\left[\mathrm{Ru}(\text { bipy })_{3}\right]^{2+}$ remained unchanged (no possible $\pi$-stacking associations), whereas it increased 1.6-fold upon the addition of AMP (see Figure S5 in the Supporting Information). These results are consistent with $\pi$-stacking interactions contributing to the recognition of adenosine phosphate derivatives. Nevertheless, compared with ionic interactions, $\pi$-stacking interactions are weak (small increase in luminescence intensity), which explains why there is no difference in the recognition of ADP and PPi (Figure 7). The stoichiometries of the complexes as well as the binding constants were determined for the adenosine phosphates (Table 2): AMP and ADP form 1:2 complexes with $\mathbf{R} \mathbf{u}_{\mathbf{5}}$,

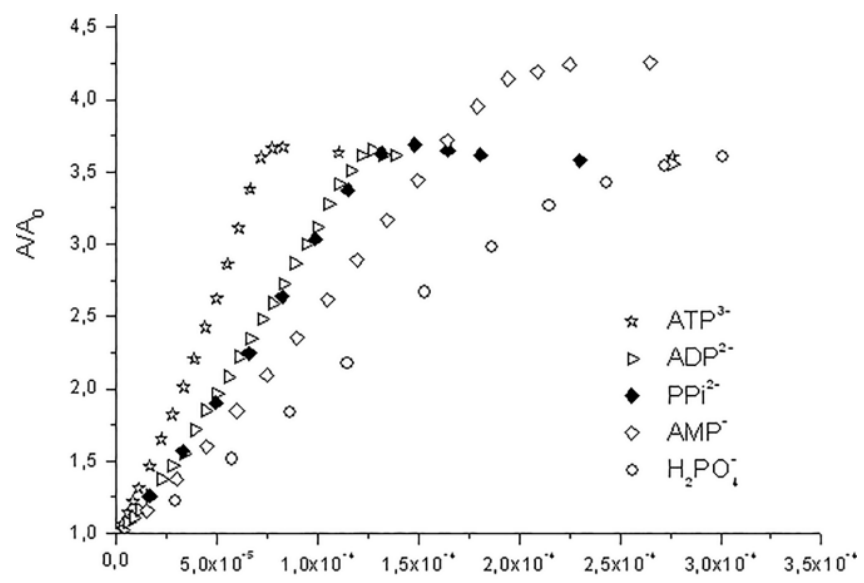

[Anion] /M

Figure 7. Relative luminescence areas of a $5 \times 10^{-6} \mathrm{M}$ solution of $\mathbf{R} \mathbf{u}_{\mathbf{5}}$ in acetonitrile as a function of concentration of nucleotides and inorganic phosphates $\left(\lambda_{\text {exc }}=490 \mathrm{~nm}, 25^{\circ} \mathrm{C}\right)$. whereas a 1:1 complex is formed with ATP (see Figure S8e-g in the Supporting Information).

Table 2. Binding constants, determined from luminescence data, for $\mathbf{R} \mathbf{u}_{\mathbf{5}^{-}}$ adenosine phosphate complexes in ACN.

\begin{tabular}{lcc}
\hline Anion & $\begin{array}{c}\text { Stoichiometries of } \\
\mathbf{R} \mathbf{u}_{\mathbf{5}} \text {-guest complexes }\end{array}$ & $\log K$ \\
\hline AMP & $1: 2$ & 7.24 \\
ADP & $1: 2$ & 9.36 \\
ATP & $1: 1$ & 5.81 \\
\hline
\end{tabular}

The binding constants can be used to compare the affinity of a probe towards various species provided the complexes formed have the same stoichiometry. As this is not the case here, we chose to compare the slopes of the titration curves. Indeed, the greater the slope of the curve, the higher the affinity of the probe. According to the curves recorded here, the strongest affinity of the probe $\mathbf{R} \mathbf{u}_{\mathbf{5}}$ is towards ATP, with ADP and PPi showing similar affinities, and the weakest interaction being observed with AMP.

This was confirmed by the binding constants measured for complexes of identical stoichiometry, that is, AMP $\left(\log K_{1: 2}=\right.$ 7.24) and ADP (log $\left.K_{1: 2}=9.36\right)$. Thus, the affinity of $\mathbf{R} \mathbf{u}_{\mathbf{5}}$ for phosphate derivatives increases with the charge of the guest, in agreement with the literature. ${ }^{[\mathrm{b}]}$ Nevertheless, the ionic interactions of ammonium phosphate are too weak in water and $\mathbf{R} \mathbf{u}_{\mathbf{5}}$ is not suitable for binding such species in aqueous media.

These results prompted us to introduce stronger complexing groups in water. Thus, we turned our attention to the zinc(II) dipicolylamine probe $\mathbf{R} \mathbf{u}_{\mathbf{7}}$. Preliminary studies conducted in acetonitrile showed that the binding of $\mathrm{AMP}, \mathrm{H}_{2} \mathrm{PO}_{4}^{-}$, and glutamate by $\mathbf{R} \mathbf{u}_{\mathbf{7}}$ led to an increase in luminescence intensity. Just as with $\mathbf{R} \mathbf{u}_{\mathbf{5}}$, selectivity for the nucleotide was observed (see Figure $\mathrm{S} 6$ in the Supporting Information). Next, binding studies in pure $25 \mathrm{~mm}$ Hepes buffered solution $(\mathrm{pH}$ 7.4) were conducted (Figure 8). Under such conditions, chloride, acetate, glutamate, and AMP did not induce any change in the luminescence intensity of the probe, whereas the addition of ADP, PPi, or ATP resulted in a significant increase in luminescence intensity as well as a $10 \mathrm{~nm}$ hypsochromic shift of the emission wavelength. The response of the probe upon addition of $20 \mu \mathrm{M}$ of anions is shown in Figure 8. The variation in luminescence intensity upon addition of ADP is shown in the inset. Contrary to what we observed in acetonitrile with $\mathbf{R} \mathbf{u}_{\mathbf{5}}$, selectivity for ADP over PPi was observed with $\mathbf{R} \mathbf{u}_{\mathbf{5}}$ in water due to $\pi$-stacking interactions. The selectivity for polyphosphates over AMP and $\mathrm{H}_{2} \mathrm{PO}_{4}{ }^{-}$is clearly a result of their different charges, but ionic interactions are not the only interaction involved in the binding, because selectivity of ADP over ATP is observed. The binding constants confirm this selectivity (Table 3 ). The higher response for ADP over ATP is ascribed to the positions of functionalization. Indeed, the $4,4^{\prime}$-modified probe $\mathbf{R} \mathbf{u}_{\mathbf{8}}$, an analogue of the 3,3'-functionalized probe $\mathbf{R} \mathbf{u}_{\mathbf{7}}$, has also been synthesized (see the Supporting Information). As for $\mathbf{R} \mathbf{u}_{\mathbf{7}}$, the $4,4^{\prime}$-modified probe detects phosphorylated species in pure Hepes buffered solution. However it is not able to discriminate between ATP and ADP (see Figure S7 in the Supporting Information). 


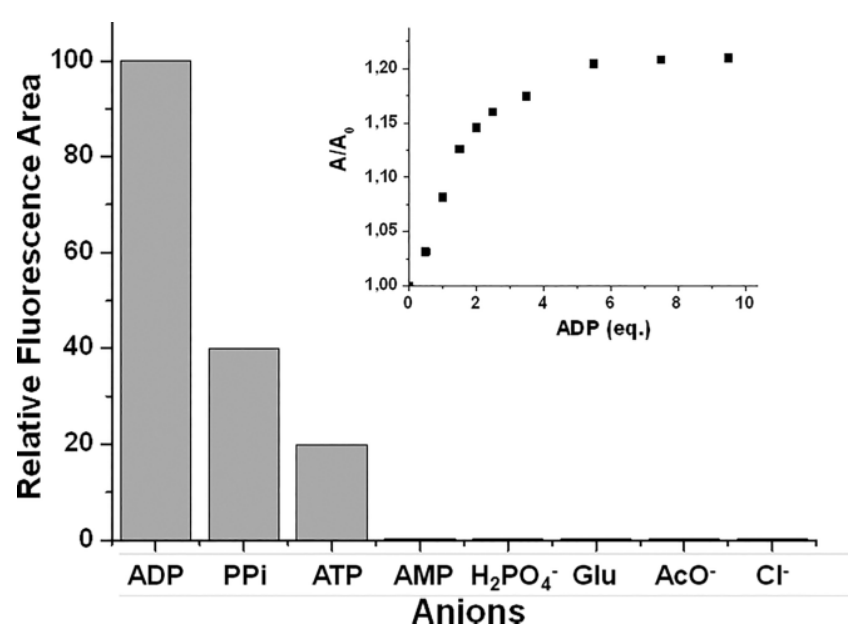

Figure 8. Relative luminescence area of a $10^{-5} \mathbf{M} \mathbf{R} \mathbf{u}_{\mathbf{7}}$ solution in Hepes ( $25 \mathrm{~mm}, \mathrm{pH} 7.4)$ against addition of 2 equiv. of anions. Inset: luminescence enhancement of $\mathbf{R} \mathbf{u}_{\mathbf{7}}$ with increasing amounts of $\operatorname{ADP}\left(\lambda_{\text {exc }}=490 \mathrm{~nm}, 20^{\circ} \mathrm{C}\right)$.

Table 3. Binding constants, determined from luminescence data, for $\mathbf{R} \mathbf{u}_{\mathbf{7}} \mathbf{-}$ anion complexes in 25 mm aqueous Hepes buffered solution ( $\mathrm{pH} 7.4)$.

\begin{tabular}{lcc}
\hline Anion & \multicolumn{2}{c}{$\begin{array}{c}\text { Stoichiometries of } \\
\mathbf{R u}_{\mathbf{7}} \text {-guest complexes }\end{array}$} \\
\hline ADP & $1: 1$ & $K\left[\mathrm{M}^{-1}\right]$ \\
ATP & $1: 1$ & $1.14 \times 10^{5}$ \\
\hline
\end{tabular}

\section{Conclusions}

Convinced by the potential of $3,3^{\prime}$-bipyridyl ruthenium complexes, we have developed a general and rapid synthesis that led to a series of novel ruthenium luminescent probes with either guanidinium, ammonium, or zinc(II) dipicolylamine binding sites. These complexes were subjected to anion complexation studies. Upon the addition of anions, the luminescence of the probes increased and a hypsochromic shift was observed. As expected, guanidinium-functionalized probes proved to be more efficient in the recognition of carboxylates. It is noteworthy that the probe $\mathbf{R} \mathbf{u}_{\mathbf{3}}$ detects glutamate preferentially to phosphates or other neurotransmitters (aspartate and GABA). On the other hand, the analogous ammonium probe $\mathbf{R u}_{\mathbf{5}}$ preferentially interacts with phosphate derivatives and more particularly with nucleotides. Moreover, as $\mathbf{R u}_{\mathbf{5}}$ is able to discriminate phosphate derivatives as a function of their respective charge, selectivity for ATP was observed within the family of adenosine phosphate derivatives. Nevertheless, these probes are not able to bind such species in aqueous media, clearly because of the solvation of anions. This difficulty has been easily circumvented through metal-anion interactions. In Hepes-buffered solution, $\mathbf{R u}_{\mathbf{7}}$ binds di- and triphosphates and is able to detect ADP selectively. This study shows that the binding of anions occurs through electrostatic and $\pi$-stacking interactions and that functionalization at the $3,3^{\prime}$-positions plays a key role in the observed selectivity.

\section{Experimental Section}

General Information and Materials: UV/Vis spectra were recorded with a Varian Cary 100 Scan spectrophotometer. Photolumines- cence spectra were collected with a Varian Eclipse fluorescence spectrophotometer. The excitation wavelength was $490 \mathrm{~nm}$ and the emission spectra were recorded between 500 and $850 \mathrm{~nm}$. All the emission spectra were corrected. Emission quantum yields were determined by using $\left[\mathrm{Ru}(\text { bipy })_{3}\right]^{2+}$ as standard, which has a known emission quantum yield of 0.062 at $25^{\circ} \mathrm{C}$ in acetonitrile. ${ }^{[19]}$ Titration experiments were carried out at $25^{\circ} \mathrm{C}$ with either $5 \times 10^{-6} \mathrm{M}$ or $5 \times 10^{-5} \mathrm{M}$ solutions of $\mathbf{R} \mathbf{u}_{\boldsymbol{i}}$ in distilled and degassed acetonitrile and increasing anion concentration. Measurements were repeated to verify their reproducibility. Photoluminescence emission $\left(A / A_{0}\right)$, based on the titration data, represents the PL emission area of the probe in the presence of the guest $(A)$ normalized to the initial PL emission area $\left(A_{0}\right)$ in the absence of the anion.

Time-resolved fluorescence measurements were performed on dilute solutions (ca. $10^{-6} \mathrm{M}$, optical density 0.1 ) in standard $1 \mathrm{~cm}$ quartz cuvettes using an Edinburgh Instruments (FLS920) spectrofluorimeter in photon-counting mode. Fluorescence lifetimes were measured by time-correlated single-photon counting (TCSPC) using the same FLS920 spectrofluorimeter. Excitation was achieved by a hydrogen-filled nanosecond flash lamp (repetition rate $40 \mathrm{kHz}$ ). The instrument response (FWHM ca. 1 ns) was determined by measuring the light scattered by a Ludox suspension.

${ }^{1} \mathrm{H}$ and ${ }^{13} \mathrm{C}$ NMR spectra were recorded with a Bruker Ultrashield Avance 400 spectrometer operating at 400.132 and $100.625 \mathrm{MHz}$, respectively. Chemical shifts are reported in ppm and are calibrated against residual solvent signals of $\mathrm{D}_{2} \mathrm{O}(\delta=4.79 \mathrm{ppm}), \mathrm{CD}_{3} \mathrm{CN}(\delta=$ $1.94,1.32,118.26 \mathrm{ppm}), \mathrm{CD}_{3} \mathrm{OD}(\delta=3.31,49.00 \mathrm{ppm})$, or $\mathrm{CDCl}_{3}(\delta=$ $7.26,77.16 \mathrm{ppm})$. All coupling constants are reported in $\mathrm{Hz}$. The following notation is used for the ${ }^{1} \mathrm{H}$ NMR spectral splitting patterns: singlet $(\mathrm{s})$, doublet $(\mathrm{d})$, triplet $(\mathrm{t})$, multiplet $(\mathrm{m})$, doublet of doublets (dd), and doublet of triplets (dt). The following notation is used for primary, secondary, tertiary, and quaternary carbon atoms, respectively: $C(\mathrm{I}), C(\mathrm{II}), C(\mathrm{III})$, and $C(\mathrm{IV})$. Liquid secondary ion mass spectra were obtained with a Waters Autospec Mass Spectrometer (EBEqQ configuration) and electrospray mass spectra with an Applied Biosystems Qstar Spectrometer (QTof configuration). Elemental analyses were performed with a Thermofischer Flash EA1112 microanalyzer.

$\mathrm{H}_{2} \mathrm{PO}_{4}^{-}, \mathrm{CH}_{3} \mathrm{CO}_{2}^{-}, \mathrm{H}_{2} \mathrm{SO}_{4}^{-}$, and halides in tetrabutylammonium salt form were purchased from Aldrich. Other anions in tetrabutylammonium salt form were obtained from the reaction between the corresponding acid and a solution of tetrabutylammonium hydroxide in water $(40 \% \mathrm{w} / \mathrm{w})$ following a synthetic procedure described in the literature. ${ }^{[22]}$ The anion salts were used after drying under vacuum. 4-(Dimethylamino)pyridine (DMAP), 1-[3-(dimethylamino)propyl]-3-ethylcarbodiimide (EDCl), $\mathrm{N}$-Boc-ethylenediamine, $\mathrm{N}$-Fmoc1,6-diaminohexane hydrobromide, 1,3-bis(tert-butoxycarbonyl)-2methyl-2-thiopseudourea, 2-(2-aminoethyl)-1,3-diBoc-guanidine, 1-hexanamine, cis-bis(2,2'-bipyridine)dichlororuthenium(II), and ammonium hexafluorophosphate were also purchased from Aldrich. 2-(6-Aminohexyl)-1,3-diBoc-guanidine and 2-(4-aminobutyl)1,3-diBoc-guanidine were synthesized from 1,3-bis(tert-butoxycarbonyl)-2-methyl-2-thiopseudourea and 1,6-diaminohexane or 1,4-diaminobutane, respectively. ${ }^{[23]}$

Spectrophotometric-grade dichloromethane and acetonitrile were purchased from Scharlau and were distilled from $\mathrm{CaH}_{2}$ and degassed before use.

Synthesis and Characterization of 2,2'-Bipyridine-3,3'-dicarboxylic Acid Bis[N-(2-guanidinoethyl)amide] Bis(hydrochloride) $\left(L_{1}\right)$ : Compound $L_{1}$ was prepared following the procedure previously described for $\mathbf{L}_{\mathbf{3}}$ from 2-(2-aminoethyl)-1,3-diBoc-guanidine 
(1 g, $3.27 \mathrm{mmol}$ ), 3,3'-dicarboxy-2,2'-bipyridine (307 mg, $1.25 \mathrm{mmol}$ ), EDCl (640 mg, $3.27 \mathrm{mmol})$, and DMAP (31 mg, $20 \mathrm{~mol}-\%) .{ }^{[12]}$ After purification by silica gel chromatography (eluent: $95: 5$ ethyl acetate/ $\left.\mathrm{Et}_{3} \mathrm{~N}\right)$ the pure intermediate was dissolved in methanol $(10 \mathrm{~mL})$ and acetyl chloride $(2 \mathrm{~mL})$ was added slowly at $0{ }^{\circ} \mathrm{C}$. The mixture, warmed to room temperature, was stirred overnight before being concentrated under reduced pressure. $\mathbf{L}_{\mathbf{1}}$ was obtained in $71 \%$ yield $(722 \mathrm{mg}, 0.888 \mathrm{mmol}) .{ }^{1} \mathrm{H}$ NMR $\left(400 \mathrm{MHz}, \mathrm{D}_{2} \mathrm{O}, 25^{\circ} \mathrm{C}\right): \delta=$ 8.84 (br. s, $2 \mathrm{H} \mathrm{Ar}, 6-\mathrm{H}, 6^{\prime}-\mathrm{H}$ ), 8.45 (d, $J=8 \mathrm{~Hz}, 2 \mathrm{H} \mathrm{Ar}, 4-\mathrm{H}, 4^{\prime}-\mathrm{H}$ ), 7.95 (br. t, $\left.2 \mathrm{H} \mathrm{Ar}, 5-\mathrm{H}, 5^{\prime}-\mathrm{H}\right), 3.55-3.35\left(\mathrm{~m}, 4 \mathrm{H}, \mathrm{CH}_{2} \mathrm{~N}\right), 3.35-3.20(\mathrm{~m}$, $\left.4 \mathrm{H}, \mathrm{CH}_{2} \mathrm{~N}\right)$ ppm. ${ }^{13} \mathrm{C}$ NMR $\left(100 \mathrm{MHz}, \mathrm{D}_{2} \mathrm{O}, 25^{\circ} \mathrm{C}\right): \delta=167.2[2 \mathrm{C}(\mathrm{IV})$, CONH], 156.9, 150.1 [4 C(IV), C=NH, C-2, C-2'], 148.0 [2 C(III) Ar, C-6, C-6'], 140.2 [2 C(III) Ar, C-4, C-4'], 132.0 [2 C(IV) Ar, C-3, C-3'], 126.4 [2 C(III) Ar, C-5, C-5'], 40.4 [2 C(II), $\left.\mathrm{CH}_{2} \mathrm{~N}\right], 38.6\left[2 \mathrm{C}(\mathrm{II}), \mathrm{CH}_{2} \mathrm{~N}\right] \mathrm{ppm}$. MS $\left(\mathrm{ESI}^{+}\right): m / z(\%)=207(100)[\mathrm{M} / 2]^{2+}, 185$ (35). HRMS (ESI $\left.{ }^{+}\right)$: calcd. for $\mathrm{C}_{18} \mathrm{H}_{26} \mathrm{~N}_{10} \mathrm{O}_{2}[\mathrm{M} / 2]^{2+}$ 207.1114; found 207.1123.

Synthesis and Characterization of 2,2'-Bipyridine-3,3'-dicarboxylic Acid Bis[N-(4-guanidinobutyl)amide] Bis(hydrochloride) $\left(L_{2}\right)$ : Compound $\mathbf{L}_{\mathbf{2}}$ was prepared following the procedure previously described for $\mathbf{L}_{\mathbf{3}}$ from 2-(4-aminobutyl)-1,3-diBoc-guanidine (1.45 g, $4.4 \mathrm{mmol}), 3,3^{\prime}$-dicarboxy-2,2'-bipyridine (244 mg, $1 \mathrm{mmol}$ ), EDCl (800 mg, $4.23 \mathrm{mmol})$, and DMAP (25 mg, $20 \mathrm{~mol}-\%) .{ }^{[12]}$ After purification by silica gel chromatography (eluent: 95:5 ethyl acetate/ $\left.\mathrm{Et}_{3} \mathrm{~N}\right)$ the pure intermediate was dissolved in methanol $(10 \mathrm{~mL})$ and acetyl chloride $(2 \mathrm{~mL})$ was added slowly at $0{ }^{\circ} \mathrm{C}$. The mixture, warmed to room temperature, was stirred overnight before being concentrated under reduced pressure. $\mathbf{L}_{\mathbf{2}}$ was obtained in $57 \%$ yield (497 mg, $0.57 \mathrm{mmol}) .{ }^{1} \mathrm{H}$ NMR $\left(400 \mathrm{MHz}, \mathrm{D}_{2} \mathrm{O}, 25^{\circ} \mathrm{C}\right): \delta=8.74$ (br. s, $\left.2 \mathrm{H} \mathrm{Ar}, 6-\mathrm{H}, 6^{\prime}-\mathrm{H}\right), 8.32$ (d, J = $8 \mathrm{~Hz}, 2 \mathrm{H} \mathrm{Ar}, 4-\mathrm{H}, 4^{\prime}-\mathrm{H}$ ), 7.83 (br. t, $\left.2 \mathrm{H} \mathrm{Ar}, 5-\mathrm{H}, 5^{\prime}-\mathrm{H}\right), 3.1-3.3\left(\mathrm{~m}, 4 \mathrm{H}, \mathrm{CH}_{2} \mathrm{~N}\right), 3.0-3.15\left(\mathrm{~m}, 4 \mathrm{H}, \mathrm{CH}_{2} \mathrm{~N}\right)$, 1.3-1.6 (m, $\left.8 \mathrm{H}, \mathrm{CH}_{2}\right)$ ppm. ${ }^{13} \mathrm{C}$ NMR $\left(100 \mathrm{MHz}, \mathrm{D}_{2} \mathrm{O}, 25^{\circ} \mathrm{C}\right): \delta=$ 167.3 [2 C(IV), CONH], 156.7, 151.1 [4 C(IV), C=NH, C-2, C-2'], 148.2 [2 C(III) Ar, C-6, C-6'], 139.4 [2 C(III) Ar, C-4, C-4'], 132.1 [2 C(IV) Ar, $\left.\mathrm{C}-3, \mathrm{C}-3^{\prime}\right], 125.9$ [2 C(III) Ar, C-5, C-5'], 39.3, 40.6 [2 C(II), $\left.\mathrm{CH}_{2} \mathrm{~N}\right], 25.4$, $25.2\left[4 \mathrm{C}(\mathrm{II}), \mathrm{CH}_{2}\right] \mathrm{ppm}$. MS $\left(\mathrm{ESI}^{+}\right): \mathrm{m} / \mathrm{z}(\%)=469(6)[\mathrm{M}-\mathrm{H}]^{+}, 235$ (100) $[\mathrm{M} / 2]^{2+}$. HRMS $\left(E S I^{+}\right)$: calcd. for $\mathrm{C}_{22} \mathrm{H}_{34} \mathrm{~N}_{10} \mathrm{O}_{2}[\mathrm{M} / 2]^{2+}$ 235.1427; found 235.1426 .

Synthesis and Characterization of 2,2'-Bipyridine-3,3'-dicarboxylic Acid Bis[N-(2-aminoethyl)amide] Hydrochloride $\left(\mathrm{L}_{4}\right)$ : $\mathrm{Com}$ pound $\mathbf{L}_{\mathbf{4}}$ was prepared following the procedure previously described for $\mathbf{L}_{\mathbf{3}}$ from tert-butyl 2-aminoethylcarbamate $(9.57 \mathrm{~g}$, $26.7 \mathrm{mmol}), 3,3^{\prime}$-dicarboxy-2,2'-bipyridine (2.23 g, $\left.9.1 \mathrm{mmol}\right), \mathrm{EDCl}$ $(6.94 \mathrm{~g}, 36.2 \mathrm{mmol})$, and DMAP (248 mg, $20 \mathrm{~mol}-\%)$. After purification by silica gel chromatography (eluent: 9:1 $\mathrm{CH}_{2} \mathrm{Cl}_{2} / \mathrm{Et}_{3} \mathrm{~N}$ ) the pure intermediate was dissolved in methanol $(150 \mathrm{~mL})$ and acetyl chloride $(4.6 \mathrm{~mL})$ was added slowly at $0{ }^{\circ} \mathrm{C}$. The mixture, warmed to room temperature, was stirred overnight before being concentrated under reduced pressure. The resulting solid was washed with a 9:1 dichloromethane/triethylamine mixture and dried to give a white solid (1.43 g, $4.35 \mathrm{mmol}, 48$ \%). M.p. $222-226^{\circ} \mathrm{C} .{ }^{1} \mathrm{H}$ NMR $(400 \mathrm{MHz}$, $\mathrm{CD}_{3} \mathrm{OD}, 25^{\circ} \mathrm{C}$ ): $\delta=8.67$ (dd, $\left.J=4.8,1.6 \mathrm{~Hz}, 2 \mathrm{H} \mathrm{Ar}, 6-\mathrm{H}, 6^{\prime}-\mathrm{H}\right), 8.14$ (dd, $\left.J=8.0,1.6 \mathrm{~Hz}, 2 \mathrm{H} \mathrm{Ar}, 4-\mathrm{H}, 4^{\prime}-\mathrm{H}\right), 7.59$ (dd, $J=8.0,4.8 \mathrm{~Hz}, 2 \mathrm{H}$ Ar, 5-H, 5'-H), $3.51\left(\mathrm{t}, J=6.4 \mathrm{~Hz}, 4 \mathrm{H}, \mathrm{CH}_{2} \mathrm{~N}\right), 3.04(\mathrm{t}, J=6.4 \mathrm{~Hz}, 4 \mathrm{H}$, $\mathrm{CH}_{2} \mathrm{~N}$ ) ppm. ${ }^{13} \mathrm{C}$ NMR (100 MHz, $\left.\mathrm{CD}_{3} \mathrm{OD}, 25{ }^{\circ} \mathrm{C}\right): \delta=171.7$ [2 C(IV), CONH], 156.3 [2 C(IV), C-2, C-2'], 150.9 [2 C(III) Ar, C-6, C-6'], 138.1 [2 C(III) Ar, C-4, C-4'], 133.2 [2 C(IV) Ar, C-3, C-3'] 124.9 [2 C(III) Ar, $\left.\mathrm{C}-5, \mathrm{C}-5^{\prime}\right], 40.5\left[2 \mathrm{C}(\mathrm{II}), \mathrm{CH}_{2} \mathrm{~N}\right], 38.6 \mathrm{ppm}$. MS $\left(\mathrm{ESI}^{+}\right): \mathrm{m} / \mathrm{z}(\%)=351$ (30) $[\mathrm{M}+\mathrm{Na}]^{+}, 329(23)[\mathrm{M}+\mathrm{H}]^{+}, 269(100)\left[\mathrm{M}-\mathrm{NHCH}_{2} \mathrm{CH}_{2} \mathrm{NH}_{2}\right]^{+}$. HRMS $\left(\mathrm{ESI}^{+}\right)$: calcd. for $\mathrm{C}_{16} \mathrm{H}_{20} \mathrm{~N}_{6} \mathrm{O}_{2} \mathrm{Na}[\mathrm{M}+\mathrm{Na}]^{+} 351.1539$; found 351.1537.

Synthesis and Characterization of 2,2'-Bipyridine-3,3'-dicarboxylic Acid Bis[N-(6-aminohexyl)amide] $\left(L_{5}\right)$ : Compound $L_{5}$ was pre- pared following the procedure previously described for $\mathbf{L}_{\mathbf{3}}$ from $\mathrm{N}$ Fmoc-1,6-diaminohexane hydrobromide (1.03 g, $2.4 \mathrm{mmol}), 3,3$ '-dicarboxy-2,2'-bipyridine (244 mg, $1 \mathrm{mmol}), \operatorname{EDCl}(1.15 \mathrm{~g}, 6 \mathrm{mmol})$, and DMAP (25 mg, 20 mol-\%). ${ }^{[12]}$ After work-up, the crude solid was washed several times with pentane. The resulting pure intermediate was dissolved in dichloromethane $(17 \mathrm{~mL})$ and piperidine $(200 \mathrm{mg}$, $2.3 \mathrm{mmol}$ ) was added to the solution at room temperature. The mixture was stirred for $24 \mathrm{~h}$ before being concentrated under vacuum. The crude product was digested several times in pentane. The resulting solid was filtered and dissolved in methanol. After concentration of the organic layer under vacuum, the product $\mathbf{L}_{\mathbf{5}}$ was obtained pure, as an oil, in $84 \%$ yield $(370 \mathrm{mg}, 0.84 \mathrm{mmol}) .{ }^{1} \mathrm{H}$ NMR (400 MHz, $\left.\mathrm{D}_{2} \mathrm{O}, 25^{\circ} \mathrm{C}\right): \delta=8.68$ (dd, $J=5.0,1.6 \mathrm{~Hz}, 2 \mathrm{H} \mathrm{Ar}, 6-$ $\left.\mathrm{H}, 6^{\prime}-\mathrm{H}\right), 8.16\left(\mathrm{dd}, J=7.9,1.6 \mathrm{~Hz}, 2 \mathrm{H} \mathrm{Ar}, 4-\mathrm{H}, 4^{\prime}-\mathrm{H}\right), 7.69$ (dd, J = 7.9, $\left.5.0 \mathrm{~Hz}, 2 \mathrm{H} \mathrm{Ar}, 5-\mathrm{H}, 5^{\prime}-\mathrm{H}\right), 3.22\left(\mathrm{t}, J=6.7 \mathrm{~Hz}, 4 \mathrm{H}, \mathrm{CH}_{2} \mathrm{NHCO}\right), 2.97(\mathrm{t}$, $\left.J=7.6 \mathrm{~Hz}, 4 \mathrm{H}, \mathrm{CH}_{2} \mathrm{NH}_{2}\right), 1.55-1.68\left(\mathrm{~m}, 4 \mathrm{H}, \mathrm{CH}_{2} \mathrm{CH}_{2} \mathrm{NH}_{2}\right), 1.25-1.45$ $\left[\mathrm{m}, 8 \mathrm{H}, \mathrm{CH}_{2}\left(\mathrm{CH}_{2}\right)_{2} \mathrm{NH}_{2}, \mathrm{CH}_{2} \mathrm{CH}_{2} \mathrm{NHCO}\right], 1.08-1.23[\mathrm{~m}, 4 \mathrm{H}$, $\left.\mathrm{CH}_{2}\left(\mathrm{CH}_{2}\right)_{2} \mathrm{NHCO}\right]$ ppm. ${ }^{13} \mathrm{C}$ NMR $\left(100 \mathrm{MHz}, \mathrm{D}_{2} \mathrm{O}, 25^{\circ} \mathrm{C}\right): \delta=169.3[2$ C(IV), CONH], 154.1 [2 C(IV) Ar, C-2, C-2'], 150.0 [2 C(III) Ar, C-6, C-6' ], 137.2 [2 C(III) Ar, C-4, C-4'], 131.5 [2 C(IV) Ar, C-3, C-3'], 124.6 [2 C(III) $\left.\mathrm{Ar}, \mathrm{C}-5, \mathrm{C}-5^{\prime}\right], 39.6\left[2 \mathrm{C}(\mathrm{II}), \mathrm{CH}_{2} \mathrm{~N}\right], 39.5\left[2 \mathrm{C}(\mathrm{II}), \mathrm{CH}_{2} \mathrm{~N}\right], 27.9[2$ $\left.\mathrm{C}(\mathrm{II}), \mathrm{CH}_{2} \mathrm{CH}_{2} \mathrm{NHCO}\right], 26.8\left[2 \mathrm{C}(\mathrm{II}), \mathrm{CH}_{2} \mathrm{CH}_{2} \mathrm{NH}_{2}\right], 25.4[2 \mathrm{C}(\mathrm{II})$, $\mathrm{CH}_{2}\left(\mathrm{CH}_{2}\right)_{2} \mathrm{NHCO}$ ], 25.2 [2 C(II), $\mathrm{CH}_{2}\left(\mathrm{CH}_{2}\right)_{2} \mathrm{NH}_{2}$ ] ppm. MS $\left(\mathrm{ESI}{ }^{+}\right): \mathrm{m} / \mathrm{z}$ $(\%)=463.4(5)[\mathrm{M}+\mathrm{Na}]^{+}, 441.3(100)[\mathrm{M}+\mathrm{H}]^{+}$. HRMS (LSI $\left.{ }^{+}\right)$: calcd. for $\mathrm{C}_{24} \mathrm{H}_{37} \mathrm{~N}_{6} \mathrm{O}_{2}[\mathrm{MH}]^{+} 441.2978$; found 441.2988 .

Synthesis and Characterization of 2,2'-Bipyridine-3,3'-dicarboxylic Acid Bis( $N$-hexylamide) $\left(\mathrm{L}_{6}\right)$ : Compound $\mathrm{L}_{6}$ was prepared following the procedure previously described for $\mathbf{L}_{\mathbf{3}}$ from distilled 1-hexanamine (483 $\mu \mathrm{L}, 3.68 \mathrm{mmol}), 3,3$ '-dicarboxy-2,2'-bipyridine (294 mg, $1.20 \mathrm{mmol}), \mathrm{EDCl}(962 \mathrm{mg}, 5.02 \mathrm{mmol}$ ), and DMAP (30 mg, 20 mol-\%). ${ }^{[12]}$ After work-up, $\mathbf{L}_{6}$ was obtained pure in $77 \%$ yield (388 mg, $0.95 \mathrm{mmol}) .{ }^{1} \mathrm{H}$ NMR $\left(400 \mathrm{MHz}, \mathrm{CDCl}_{3}, 25^{\circ} \mathrm{C}\right): \delta=8.56$ (dd, $\left.J=1.6,5.2 \mathrm{~Hz}, 2 \mathrm{H} \mathrm{Ar}, 6-\mathrm{H}, 6^{\prime}-\mathrm{H}\right), 7.92(\mathrm{dd}, J=1.6,8.0 \mathrm{~Hz}, 2 \mathrm{H} \mathrm{Ar}$, $\left.4-\mathrm{H}, 4^{\prime}-\mathrm{H}\right), 7.47(\mathrm{t}, J=4.8 \mathrm{~Hz}, 2 \mathrm{H}, \mathrm{NH}), 7.33(\mathrm{dd}, J=5.2,8.0 \mathrm{~Hz}, 2 \mathrm{H}$ $\left.\mathrm{Ar}, 5-\mathrm{H}, 5^{\prime}-\mathrm{H}\right), 3.13\left(\mathrm{dt}, J=4.8,6.8 \mathrm{~Hz}, 4 \mathrm{H}, \mathrm{CH}_{2} \mathrm{NHCO}\right), 1.33-1.09[\mathrm{~m}$, $16 \mathrm{H}, \mathrm{CH}_{3}\left(\mathrm{CH}_{2}\right)_{4} \mathrm{CH}_{2} \mathrm{NHCO}$, $0.85\left(\mathrm{t}, J=6.8 \mathrm{~Hz}, 6 \mathrm{H}, \mathrm{CH}_{3}\right) \mathrm{ppm} .{ }^{13} \mathrm{C}$ NMR $\left(100 \mathrm{MHz}_{1} \mathrm{CDCl}_{3}, 25^{\circ} \mathrm{C}\right): \delta=168.0$ [2 C(IV), $\left.\mathrm{CONH}\right], 156.5[2$ C(IV) Ar, C-2, C-2'], 149.6 [2 C(III) Ar, C-6, C-6'], 135.9 [2 C(III) Ar, C-4, C-4'], 132.6 [2 C(IV) Ar, C-3, C-3'], 123.2 [2 C(III) Ar, C-5, C-5'], 40.0 [2 $\mathrm{C}(\mathrm{II}), \mathrm{CH}_{2} \mathrm{~N}$ ], 31.6 [2 $\left.\mathrm{C}(\mathrm{II}), \mathrm{CH}_{2} \mathrm{CH}_{2} \mathrm{CH}_{3}\right], 29.4$ [2 C(II), $\mathrm{CH}_{2} \mathrm{CH}_{2} \mathrm{NHCO}$, $26.5\left[2 \mathrm{C}(\mathrm{II}), \mathrm{CH}_{2}\left(\mathrm{CH}_{2}\right)_{2} \mathrm{NHCO}\right], 22.6\left[2 \mathrm{C}(\mathrm{II}), \mathrm{CH}_{2} \mathrm{CH}_{3}\right], 14.1[2 \mathrm{C}(\mathrm{I})$, $\left.\mathrm{CH}_{3}\right]$ ppm. MS $\left(\mathrm{ESI}^{+}\right): \mathrm{m} / \mathrm{z}(\%)=433(100)[\mathrm{M}+\mathrm{Na}]^{+}, 843(43)\left[\mathrm{M}_{2}+\right.$ $\mathrm{Na}]^{+}$. HRMS $\left(\mathrm{ESI}^{+}\right)$: calcd. for $\mathrm{C}_{24} \mathrm{H}_{34} \mathrm{~N}_{4} \mathrm{O}_{2} \mathrm{Na}[\mathrm{M}+\mathrm{Na}]^{+}$433.2573; found 433.2578 .

Synthesis and Characterization of $\mathbf{R u _ { 1 }}$ : Complex $\mathbf{R \mathbf { u } _ { 1 }}$ was prepared according to the synthesis previously described for $\mathbf{R} \mathbf{u}_{\mathbf{3}}$ from dihydrated cis-bis(2,2'-bipyridine)dichlororuthenium(II) (126 mg, $0.258 \mathrm{mmol})$ and $\mathbf{L}_{\mathbf{1}}(150 \mathrm{mg}, 0.31 \mathrm{mmol}) .{ }^{[12]}$ After purification by silica gel chromatography (eluent: 80:15:5 $\mathrm{CH}_{3} \mathrm{CN} / \mathrm{H}_{2} \mathrm{O} / \mathrm{KNO}_{3}$ saturated aqueous solution) and elimination of $\mathrm{KNO}_{3}$ by successive precipitations in methanol, the orange product was dissolved in a minimum of distilled water. $\mathbf{R} \mathbf{u}_{\mathbf{1}}$ was recovered as the hexafluorophosphate salt in $68 \%$ yield ( $247 \mathrm{mg}, 0.175 \mathrm{mmol}$ ) by precipitation upon the addition of an aqueous saturated solution of ammonium hexafluorophosphate. M.p. $214-216^{\circ} \mathrm{C} .{ }^{1} \mathrm{H}$ NMR $\left(400 \mathrm{MHz}, \mathrm{CD}_{3} \mathrm{CN}, 25^{\circ} \mathrm{C}\right)$ : $\delta=8.52\left(\mathrm{dd}, J=8.1,3.6 \mathrm{~Hz}, 4 \mathrm{H} \mathrm{Ar}, 3-\mathrm{H}, 3^{\prime}-\mathrm{H}\right.$ of bipy), 8.20-8.03 (m, $6 \mathrm{H} \mathrm{Ar}, 4-\mathrm{H}, 4^{\prime}-\mathrm{H}$ of $\mathrm{L}_{1}$ and bipy), $7.88\left(\mathrm{~d}, J=5.6 \mathrm{~Hz}, 2 \mathrm{H} \mathrm{Ar}, 6-\mathrm{H}, 6^{\prime}-\right.$ $\mathrm{H}$ of $\left.\mathbf{L}_{\mathbf{1}}\right), 7.69\left(\mathrm{~d}, J=5.3 \mathrm{~Hz}, 2 \mathrm{H} \mathrm{Ar}, 6-\mathrm{H}, 6^{\prime}-\mathrm{H}\right.$ of bipy), 7.55-7.35 (2 $\mathrm{m}, 2 \mathrm{H}, 6 \mathrm{H} \mathrm{Ar}, \mathrm{NH}$ amide, 5- $\mathrm{H}, 5^{\prime}-\mathrm{H}$ of $\mathbf{L}_{1}$ and bipy), 7.26 (br. $\mathrm{t}, J=$ $5.0 \mathrm{~Hz}, 2 \mathrm{H}, \mathrm{NH}$ guanidine), 6.35 (br. s, $\left.8 \mathrm{H}, \mathrm{NH}_{2}\right), 3.47-3.30(2 \mathrm{~m}, 4$ $\mathrm{H}, \mathrm{CH}_{2} \mathrm{NHCO}$, cis/trans isomers), 3.35-3.25 (m, $4 \mathrm{H}, \mathrm{CH}_{2}$-guanidine) ppm. ${ }^{13} \mathrm{C}$ NMR $\left(100 \mathrm{MHz}, \mathrm{CD}_{3} \mathrm{CN}, 25^{\circ} \mathrm{C}\right): \delta=166.6$ [2 C(IV), $\mathrm{CONH}$ ], 157.9, 157.8, 156.0 [6 C(IV), C-2, C-2' of $\mathbf{L}_{1}$ and bipy], 152.8 
[2 C(IV), CN $\mathrm{CN}_{3}$ ], 153.7, 152.6 [6 C(III) Ar, C-6, C-6' of $\mathbf{L}_{\mathbf{1}}$ and bipy], 138.9, 138.8 [6 C(III) Ar, C-4, C-4' of $\mathbf{L}_{\mathbf{1}}$ and bipy], 137.7 [2 C(IV) Ar, $\mathrm{C}-3, \mathrm{C}-3^{\prime}$ of $\mathrm{L}_{1}$ ] $, 128.6,128.5$, [4 C(III) Ar, C-5, C-5' of bipy], 128.0 [2 C(III) Ar, C-5, C-5' of $\mathbf{L}_{1}$ ], 125.21, 125.17 [4 C(III) Ar, C-3, C-3' of bipy], 41.0 [2 C(II), $\mathrm{CH}_{2}$ guanidine], 39.8 [2 C(II), $\left.\mathrm{CH}_{2} \mathrm{NHCO}\right]$ ppm. MS (ESI $\left.{ }^{+}\right)$: $m / z(\%)=1430.6(8)\left[\mathrm{M}+\mathrm{Na}+2 \mathrm{H}+4 \mathrm{PF}_{6}\right]^{+}, 1284.7(5)[\mathrm{M}+\mathrm{Na}+$ $\left.\mathrm{H}+3 \mathrm{PF}_{6}\right]^{+}, 1262.9(48)\left[\mathrm{M}+2 \mathrm{H}+3 \mathrm{PF}_{6}\right]^{+}, 1117.1(100)[\mathrm{M}+\mathrm{H}+$ $\left.2 \mathrm{PF}_{6}\right]^{+}, 971.1$ (36) $\left[\mathrm{M}+\mathrm{PF}_{6}\right]^{+}, 486.0$ (17) $\left[\mathrm{M}+\mathrm{H}+\mathrm{PF}_{6}\right]^{+}, 413.1$ (30) $[\mathrm{M} / 2]^{2+}$. HRMS $\left(\mathrm{LSI}^{+}\right)$: calcd. for $\mathrm{C}_{38} \mathrm{H}_{40} \mathrm{~N}_{14} \mathrm{O}_{2} \mathrm{~F}_{18} \mathrm{P}_{3} \mathrm{Ru}[\mathrm{M}+2 \mathrm{H}+3$ $\left.\mathrm{PF}_{6}\right]^{+}$1263.1584; found 1263.1628. $\mathrm{C}_{38} \mathrm{H}_{42} \mathrm{~F}_{24} \mathrm{~N}_{14} \mathrm{O}_{2} \mathrm{P}_{4} \mathrm{Ru} \cdot 2 \mathrm{H}_{2} \mathrm{O}$ (1443.81): C 31.61, H 3.21, N 13.58; found C 31.50, H 3.06, N 13.57.

Synthesis and Characterization of $\mathbf{R u}_{\mathbf{2}}$ : Complex $\mathbf{R} \mathbf{u}_{\mathbf{2}}$ was prepared according to the synthesis previously described for $\mathbf{R} \mathbf{u}_{\mathbf{3}}$ from dihydrated cis-bis(2,2'-bipyridine)dichlororuthenium(II) (77 mg, $0.154 \mathrm{mmol}$ ) and $\mathbf{L}_{\mathbf{2}}(92 \mathrm{mg}, 0.17 \mathrm{mmol}){ }^{[12]}$ After purification by silica gel chromatography (eluent: $80: 15: 5 \mathrm{CH}_{3} \mathrm{CN} / \mathrm{H}_{2} \mathrm{O} / \mathrm{KNO}_{3}$ saturated aqueous solution) and elimination of $\mathrm{KNO}_{3}$ by successive precipitations in methanol, the orange product was dissolved in a minimum of distilled water. $\mathbf{R} \mathbf{u}_{\mathbf{2}}$ was recovered as the hexafluorophosphate salt in $73 \%$ yield ( $166 \mathrm{mg}, 0.113 \mathrm{mmol}$ ) by precipitation upon the addition of an aqueous saturated solution of ammonium hexafluorophosphate. M.p. $175-180^{\circ} \mathrm{C} .{ }^{1} \mathrm{H}$ NMR $\left(400 \mathrm{MHz}, \mathrm{CD}_{3} \mathrm{CN}, 25^{\circ} \mathrm{C}\right)$ : $\delta=8.53\left(\mathrm{dd}, J=8.1,4.6 \mathrm{~Hz}, 2 \mathrm{H} \mathrm{Ar}, 3-\mathrm{H}, 3^{\prime}-\mathrm{H}\right.$ of bipy), 8-8.2 (m, 6 $\mathrm{H} \mathrm{Ar}, 4-\mathrm{H}, 4^{\prime}-\mathrm{H}$ of $\mathbf{L}_{2}$ and bipy), $7.84\left(\mathrm{~d}, J=5.1 \mathrm{~Hz}, 2 \mathrm{H} \mathrm{Ar}, 6-\mathrm{H}, 6^{\prime}-\mathrm{H}\right.$ of $\left.\mathbf{L}_{2}\right), 7.68\left(\mathrm{~d}, J=5.4 \mathrm{~Hz}, 2 \mathrm{H} \mathrm{Ar}, 6-\mathrm{H}, 6^{\prime}-\mathrm{H}\right.$ of bipy), 7.55-7.35 (m, 6 $\mathrm{H} \mathrm{Ar}, 5-\mathrm{H}, 5^{\prime}-\mathrm{H}$ of $\mathbf{L}_{\mathbf{2}}$ and bipy), $7.28(\mathrm{t}, J=5.7 \mathrm{~Hz}, 2 \mathrm{H}, \mathrm{NHCO}), 6.51$ (br. $\mathrm{t}, J=5.6 \mathrm{~Hz}, 2 \mathrm{H}, \mathrm{NH}$ guanidine), 6.3-5.8 (br. $\mathrm{s}, 6 \mathrm{H}, \mathrm{NH}_{2}$ ), 1.51.65 ( $\left.\mathrm{m}, 8 \mathrm{H}, \mathrm{CH}_{2}\right), 3.40-3.15$ ( $2 \mathrm{~m}, 4 \mathrm{H}, \mathrm{CH}_{2} \mathrm{NHCO}$, cis/trans isomers), 3.25-3.10 (m, $4 \mathrm{H}, \mathrm{CH}_{2}$ guanidine) ppm. ${ }^{13} \mathrm{C} \mathrm{NMR}\left(100 \mathrm{MHz}, \mathrm{CD}_{3} \mathrm{CN}\right.$, $\left.25^{\circ} \mathrm{C}\right): \delta=165.7$ [2 C(IV), CONH] $157.9,157.8,157.7,157.5,157.4$, 157.0 [2 C(IV), 6 C(IV) Ar, $2 \mathrm{CN}_{3}, \mathrm{C}-2, \mathrm{C}-2^{\prime}$ of bipy and $\mathrm{L}_{2}$ ], 153.1, 152.64, 152.6, [6 C(III) Ar, C-6, C-6' of $\mathbf{L}_{\mathbf{2}}$ and bipy], 138.5 [2 C(IV) $\mathrm{Ar}$, C-3, C-3' of $\mathbf{L}_{2}$ ], 138.9, 138.8, 138.0 [6 C(III) Ar, C-4, C-4' of bipy and $\mathbf{L}_{2}$ ], 128.5, 128.4 [4 C(III) Ar, C-5, C-5' of bipy], 127.7 [2 C(III) Ar, C-5, C-5' of $\mathbf{L}_{2}$ ], 125.3 [4 C(III) Ar, C-3, C-3' of bipy], 42.0 [2 C(II), $\mathrm{CH}_{2}$ guanidine], $40.2\left[2 \mathrm{C}(\mathrm{II}), \mathrm{CH}_{2} \mathrm{NHCO}\right], 26.7\left[2 \mathrm{C}(\mathrm{II}), \mathrm{CH}_{2}\right], 26.3[2 \mathrm{C}(\mathrm{II})$, $\left.\mathrm{CH}_{2}\right]$ ppm. MS $\left(\mathrm{LSI}^{+}\right): \mathrm{m} / \mathrm{z}(\%)=1318(53)\left[\mathrm{M}+\mathrm{H}+3 \mathrm{PF}_{6}\right]^{+}, 1173$ (20) $\left[\mathrm{M}+\mathrm{H}+2 \mathrm{PF}_{6}\right]^{+}, 1027(15)\left[\mathrm{M}+\mathrm{PF}_{6}\right]^{+}, 881$ (10) $[\mathrm{M}-\mathrm{H}]^{+}$. HRMS (LSI ${ }^{+}$): calcd. for $\mathrm{C}_{42} \mathrm{H}_{50} \mathrm{~N}_{14} \mathrm{O}_{2} \mathrm{~F}_{18} \mathrm{P}_{3} \mathrm{Ru}\left[\mathrm{M}+2 \mathrm{H}_{2}+3 \mathrm{PF}_{6}\right]^{+}$1319.2210; found 1319.2251. $\mathrm{C}_{42} \mathrm{H}_{50} \mathrm{~F}_{24} \mathrm{~N}_{14} \mathrm{O}_{2} \mathrm{P}_{4} \mathrm{Ru} \cdot \mathrm{H}_{2} \mathrm{O}$ (1481.90): calcd. C 34.03, H 3.54, N 13.23;; found C 34.29, H 3.77, N 13.18 .

Synthesis and Characterization of $\mathbf{R u}_{\mathbf{4}}$ : Complex $\mathbf{R} \mathbf{u}_{\mathbf{4}}$ was prepared according to the synthesis previously described for $\mathbf{R} \mathbf{u}_{\mathbf{3}}$ from dihydrated cis-bis(2,2'-bipyridine)dichlororuthenium(II) (737 mg, $1.51 \mathrm{mmol})$ and $\mathbf{L}_{\mathbf{4}}(500 \mathrm{mg}, 1.51 \mathrm{mmol}){ }^{[12]}$ After purification by silica gel chromatography (eluent: 85:12.5:2.5 $\mathrm{CH}_{3} \mathrm{CN} / \mathrm{H}_{2} \mathrm{O} / \mathrm{KNO}_{3}$ saturated aqueous solution) and elimination of $\mathrm{KNO}_{3}$ by successive precipitations in methanol, the orange product was dissolved in a minimum of distilled water. $\mathbf{R} \mathbf{u}_{\mathbf{4}}$ was recovered as the hexafluorophosphate salt in $54 \%$ yield $(1.2 \mathrm{~g}$ containing $11 \%$ weight of $\mathrm{NH}_{4} \mathrm{PF}_{6}$ or about $1.08 \mathrm{~g}$ of $\mathbf{R u}_{\mathbf{4}}, 0.815 \mathrm{mmol}$ ) by precipitation upon the addition of an aqueous saturated solution of ammonium hexafluorophosphate. M.p. $236^{\circ} \mathrm{C} .{ }^{1} \mathrm{H}$ NMR $\left(400 \mathrm{MHz}, \mathrm{MeOD}, 25^{\circ} \mathrm{C}\right): \delta=$ $8.66\left(\mathrm{~d}, J=8.1 \mathrm{~Hz}, 4 \mathrm{H} \mathrm{Ar}, 3-\mathrm{H}, 3^{\prime}-\mathrm{H}\right.$ of bipy), 8.18 (d, $J=7.7 \mathrm{~Hz}, 2$ $\mathrm{H}$ Ar, 4-H, 4'-H of bipy), 8.25-8.07 (m, $4 \mathrm{H} \mathrm{Ar}, 4-\mathrm{H}, 4^{\prime}-\mathrm{H}$ of bipy), 7.94 $\left(\mathrm{d}, J=5.5 \mathrm{~Hz}, 2 \mathrm{H} \mathrm{Ar}, 6-\mathrm{H}, 6^{\prime}-\mathrm{H}\right.$ of $\left.\mathbf{L}_{4}\right), 7.71(\mathrm{~d}, J=5.6 \mathrm{~Hz}, 2 \mathrm{H} \mathrm{Ar}, 6-$ $\mathrm{H}, 6^{\prime}-\mathrm{H}$ of bipy), 7.60-7.42 (2 m, $6 \mathrm{H} \mathrm{Ar}, 5-\mathrm{H}, 5^{\prime}-\mathrm{H}$ of $\mathbf{L}_{\mathbf{4}}$ and bipy), 3.75-3.54 (2 m, $4 \mathrm{H}, \mathrm{CH}_{2} \mathrm{NHCO}$, cis/trans isomers), 3.25-3.12 (m, $4 \mathrm{H}$, $\left.\mathrm{CH}_{2} \mathrm{NH}_{3}{ }^{+}\right)$ppm. ${ }^{13} \mathrm{C}$ NMR $\left(100 \mathrm{MHz}, \mathrm{MeOD}, 25^{\circ} \mathrm{C}\right): \delta=168.4[2 \mathrm{C}(\mathrm{IV})$, $\mathrm{CONH}$ ], 158.7, 158.4, 158.0 [6 C(IV) $\mathrm{Ar}, \mathrm{C}-2, \mathrm{C}-2^{\prime}$ of $\mathbf{L}_{\mathbf{4}}$ and bipy], 153.7, 153.4, 152.9 [6 C(III) Ar, C-6, C-6' of $\mathbf{L}_{\mathbf{4}}$ and bipy], 139.6 [4 C(III) Ar, C-4, C-4' of bipy], 139.0 [2 C(III) Ar, C-4, C-4' of $\mathbf{L}_{\mathbf{4}}$ ], 138.2 [2 C(IV) Ar, C-3, C-3' of $\mathbf{L}_{\mathbf{4}}$ ], 129.2, 129.1 [4 C(III) Ar, 4 CH, C-5, C-5' of bipy], 128.3 [2 C(III) Ar, C-5, C-5' of $\mathbf{L}_{\mathbf{4}}$ ], 125.8, 125.7 [4 C(III) Ar, C-3, C-3' of bipy], 41.0 [2 C(II), $\left.\mathrm{CH}_{2} \mathrm{NH}_{3}{ }^{+}\right], 39.4$ [2 C(II), $\left.\mathrm{CH}_{2} \mathrm{NHCO}\right]$ ppm. MS $\left(\mathrm{ESI}^{+}\right): \mathrm{m} / \mathrm{z}(\%)=371(100)[\mathrm{M} / 2]^{2+}$. HRMS $\left(\mathrm{ESI}^{+}\right)$: calcd. for $\mathrm{C}_{36} \mathrm{H}_{36} \mathrm{~N}_{10} \mathrm{O}_{2} \mathrm{Ru}[\mathrm{M} / 2]^{2+}$ 371.1027; found 371.1014.

Synthesis and Characterization of $\mathbf{R} \mathbf{u}_{5}$ : Complex $\mathbf{R} \mathbf{u}_{5}$ was prepared according to the synthesis previously described for $\mathbf{R} \mathbf{u}_{\mathbf{3}}$ from dihydrated cis-bis(2,2'-bipyridine)dichlororuthenium(II) (78 mg, $0.16 \mathrm{mmol})$ and $\mathbf{L}_{\mathbf{5}}(71 \mathrm{mg}, 0.16 \mathrm{mmol}) .{ }^{[12]}$ After purification by silica gel chromatography [eluent: 9:0.5:0.5 $\mathrm{CH}_{3} \mathrm{CN} / \mathrm{H}_{2} \mathrm{O} / \mathrm{KNO}_{3}$ saturated aqueous solution) and elimination of $\mathrm{KNO}_{3}$ by successive precipitations in methanol, the orange product was dissolved in a minimum of distilled water. $\mathbf{R} \mathbf{u}_{\mathbf{5}}$ was recovered as the hexafluorophosphate salt in $52 \%$ yield $(115 \mathrm{mg}, 0.083 \mathrm{mmol}$ ) by precipitation upon the addition of an aqueous saturated solution of ammonium hexafluorophosphate. M.p. $199-200{ }^{\circ} \mathrm{C} .{ }^{1} \mathrm{H}$ NMR $\left(400 \mathrm{MHz}, \mathrm{D}_{2} \mathrm{O}, 25^{\circ} \mathrm{C}\right)$ : $\delta=8.59\left(\mathrm{dd}, J=7.7,1.7 \mathrm{~Hz}, 4 \mathrm{H}, \mathrm{Ar}, 3-\mathrm{H}, 3^{\prime}-\mathrm{H}\right.$ of bipy), 8.20-7.95 ( $\mathrm{m}, 6 \mathrm{H} \mathrm{Ar}, 4-\mathrm{H}, 4^{\prime}-\mathrm{H}$ of $\mathrm{L}_{5}$ and bipy), 8.02 (d, J= $5.1 \mathrm{~Hz}, 2 \mathrm{H} \mathrm{Ar}, 6-$ $\mathrm{H}, 6^{\prime}-\mathrm{H}$ of $\left.\mathrm{L}_{5}\right), 7.79\left(\mathrm{~d}, J=5.3 \mathrm{~Hz}, 2 \mathrm{H} \mathrm{Ar}, 6-\mathrm{H}, 6^{\prime}-\mathrm{H}\right.$ of bipy), 7.62$7.35\left(2 \mathrm{~m}, 6 \mathrm{H} \mathrm{Ar}, 5-\mathrm{H}, 5^{\prime}-\mathrm{H}\right.$ of $\mathbf{L}_{5}$ and bipy), 3.55-3.25 $(2 \mathrm{~m}, 4 \mathrm{H}$, $\mathrm{CH}_{2} \mathrm{NHCO}$, cis/trans isomers), $3.15\left(\mathrm{t}, J=7.6 \mathrm{~Hz}, 4 \mathrm{H}, \mathrm{CH}_{2} \mathrm{NH}_{3}{ }^{+}\right), 1.85-$ $1.65\left(\mathrm{~m}, 4 \mathrm{H}, \mathrm{CH}_{2} \mathrm{CH}_{2} \mathrm{NH}_{3}{ }^{+}\right), 1.75-1.60\left(\mathrm{~m}, 4 \mathrm{H}, \mathrm{CH}_{2} \mathrm{CH}_{2} \mathrm{NHCO}\right), 1.55-$ $1.35\left(\mathrm{~m}, 8 \mathrm{H}, \mathrm{CH}_{2}\right)$ ppm. ${ }^{13} \mathrm{C} \mathrm{NMR}\left(100 \mathrm{MHz}, \mathrm{D}_{2} \mathrm{O}, 25^{\circ} \mathrm{C}\right): \delta=166.7$ [2 C(IV), CONH], 157.0, 156.9, 156.3 [6 C(IV) Ar, C-2, C-2' of $\mathbf{L}_{5}$ and bipy], 152.6, 151.8, 151.6 [6 C(III) Ar, 6CH, C-6, C-6' of $\mathbf{L}_{5}$ and bipy], 138.0, 137.9, [4 C(III) Ar, C-4, C-4' of bipy], 137.0 [2 C(III) Ar, C-4, C$4^{\prime}$ of $\mathbf{L}_{5}$ ], 136.7 [2 C(IV) Ar, C-3, C-3' of $\mathbf{L}_{5}$ ], 127.4 [4 C(III) Ar, C-5, C$5^{\prime}$ of bipy], 126.8 [2 C(III) Ar, C-5, C-5' of $\mathbf{L}_{5}$ ], 124.2 [4 C(III) Ar, C-3, C-3' of bipy], 40.5 [2 C(II), $\mathrm{CH}_{2} \mathrm{NHCO}$, 39.6 [2 C(II), $\left.\mathrm{CH}_{2} \mathrm{NH}_{3}{ }^{+}\right], 28.0$ [2 $\mathrm{C}(\mathrm{II}), \mathrm{CH}_{2} \mathrm{CH}_{2} \mathrm{NHCO}$ ], 26.7 [2 C(II), $\mathrm{CH}_{2} \mathrm{CH}_{2} \mathrm{NH}_{3}{ }^{+}$], 25.9 [2 C(II), $\mathrm{CH}_{2}$ ], $25.4\left[2 \mathrm{C}(\mathrm{II}), \mathrm{CH}_{2}\right]$ ppm. MS $\left(\mathrm{LSI}^{+}\right): \mathrm{m} / z(\%)=1330(54)[\mathrm{M}+2 \mathrm{H}+\mathrm{K}$ $\left.+3 \mathrm{PF}_{6}\right]^{+}, 1290(26)\left[\mathrm{M}+\mathrm{H}+3 \mathrm{PF}_{6}\right]^{+}, 1225(20), 1185(59)[\mathrm{M}+2 \mathrm{H}+$ $\left.\mathrm{K}+2 \mathrm{PF}_{6}\right]^{+}, 1145(39)\left[\mathrm{M}+\mathrm{H}+2 \mathrm{PF}_{6}\right]^{+}, 1039(100)\left[\mathrm{MHK}+\mathrm{PF}_{6}\right]^{+}, 999$ (94) $\left[\mathrm{M}+\mathrm{PF}_{6}\right]^{+}, 894(50)[\mathrm{M}+\mathrm{H}+\mathrm{K}]^{+}, 854$ (41) $[\mathrm{M}]^{+}, 750$ (21), 710 (24). MS [ESI $\left.{ }^{+}\right]: m / z(\%)=999.1(85)\left[\mathrm{M}+\mathrm{PF}_{6}\right]^{+}, 853.3(38)[\mathrm{M}-\mathrm{H}]^{+}$, $442.1(11)\left[\mathrm{L}_{5}+\mathrm{H}\right]^{+}, 427.3(100)[\mathrm{M} / 2]^{2+}, 285.1(15)[(\mathrm{M}+\mathrm{H}) / 3]^{3+}$, $224.7(5)\left[\left(\mathbf{L}_{5}+2 \mathrm{H}\right) / 2\right]^{2+}$. HRMS $\left(\mathrm{LSI}^{+}\right)$: calcd. for $\mathrm{C}_{44} \mathrm{H}_{52} \mathrm{~N}_{10} \mathrm{O}_{2} \mathrm{~F}_{6} \mathrm{PRu}$ $[\mathrm{M}+\mathrm{H}]^{+}$999.2960; found 999.2956. $\mathrm{C}_{44} \mathrm{H}_{54} \mathrm{~F}_{24} \mathrm{~N}_{10} \mathrm{O}_{2} \mathrm{P}_{4} \mathrm{Ru} \cdot\left(\mathrm{HPF}_{6}\right)_{0.5}$ (1508.90): calcd. C 35.02, H 3.64, N 9.28; found C 35.26, H 3.61, N 9.08 .

Synthesis and Characterization of $\mathbf{R u}_{6}$ : Complex $\mathbf{R} \mathbf{u}_{6}$ was prepared according to the synthesis previously described for $\mathbf{R} \mathbf{u}_{\mathbf{3}}$ from dihydrated cis-bis(2,2'-bipyridine)dichlororuthenium(II) (192 mg, $0.40 \mathrm{mmol})$ and $\mathbf{L}_{6}(146 \mathrm{mg}, 0.35 \mathrm{mmol}) .{ }^{[12]}$ After purification by silica gel chromatography (eluent: $100 \% \mathrm{CH}_{3} \mathrm{CN}$ to $7: 2: 1 \mathrm{CH}_{3} \mathrm{CN}$ / $\mathrm{H}_{2} \mathrm{O} / \mathrm{KNO}_{3}$ saturated aqueous solution) and elimination of $\mathrm{KNO}_{3}$ by successive precipitations in methanol, the orange product was dissolved in a minimum of distilled water. $\mathbf{R u}_{\mathbf{6}}$ was recovered as the hexafluorophosphate salt in $76 \%$ yield $(296 \mathrm{mg}, 0.27 \mathrm{mmol}$ ) by precipitation upon the addition of an aqueous saturated solution of ammonium hexafluorophosphate. M.p. $180{ }^{\circ} \mathrm{C} .{ }^{1} \mathrm{H}$ NMR $(400 \mathrm{MHz}$, $\left.\mathrm{CD}_{3} \mathrm{CN}, 25^{\circ} \mathrm{C}\right): \delta=8.50\left(\mathrm{dd}, J=8.0,3.6 \mathrm{~Hz}, 4 \mathrm{H} \mathrm{Ar}, 3-\mathrm{H}, 3^{\prime}-\mathrm{H}\right.$ of bipy), 8.05-8.15 (m, $4 \mathrm{H} \mathrm{Ar}, 4-\mathrm{H}, 4^{\prime}-\mathrm{H}$ of bipy), 7.96 (d, J = 7.6 Hz, 2 $\mathrm{H} \mathrm{Ar}, 4-\mathrm{H}, 4^{\prime}-\mathrm{H}$ of $\left.\mathbf{L}_{6}\right), 7.76\left(\mathrm{dd}, J=5.6,1.6 \mathrm{~Hz}, 2 \mathrm{H} \mathrm{Ar}, 6-\mathrm{H}, 6^{\prime}-\mathrm{H}\right.$ of $\left.\mathbf{L}_{6}\right), 7.66\left(\mathrm{~d}, J=5.2 \mathrm{~Hz}, 2 \mathrm{H} \mathrm{Ar}, 6-\mathrm{H}, 6^{\prime}-\mathrm{H}\right.$ of bipy), 7.30-7.50 (2 m, 6 $\mathrm{H} \mathrm{Ar}, 5-\mathrm{H}, 5^{\prime}-\mathrm{H}$ of $\mathbf{L}_{6}$ and bipy), $7.25(\mathrm{t}, J=6.0 \mathrm{~Hz}, 2 \mathrm{H}, \mathrm{NH}), 3.07-$ $3.40\left(2 \mathrm{~m}, 4 \mathrm{H}, \mathrm{CH}_{2} \mathrm{NHCO}\right.$, cis/trans isomers), $1.45-1.60(\mathrm{~m}, 4 \mathrm{H}$, $\left.\mathrm{CH}_{2} \mathrm{CH}_{2} \mathrm{NHCO}\right), 1.25-1.45\left[\mathrm{~m}, 12 \mathrm{H}, \mathrm{CH}_{3}\left(\mathrm{CH}_{2}\right)_{3}\right], 0.90(\mathrm{t}, J=6.8 \mathrm{~Hz}, 6$ $\mathrm{H}, \mathrm{CH}_{3}$ ) ppm. ${ }^{13} \mathrm{C}$ NMR (100 MHz, $\left.\mathrm{CD}_{3} \mathrm{CN}, 25^{\circ} \mathrm{C}\right): \delta=165.5$ [2 C(IV), $\mathrm{CONH}$ ], 158.0, 157.8 [6 C(IV) Ar, C-2, C-2' of $\mathbf{L}_{6}$ and bipy], 152.9, 152.8 [6 C(III) Ar, $6 \mathrm{CH}, \mathrm{C}-6, \mathrm{C}-6^{\prime}$ of $\mathbf{L}_{5}$ and bipy], 139.2 [2 C(IV) Ar, C-3, C-3' of $\mathbf{L}_{6}$ ], 139.1, 139.0 [4 C(III) Ar, C-4, C-4' of bipy], 137.8 [2 C(III) $\mathrm{Ar}, \mathrm{C}-4, \mathrm{C}-4^{\prime}$ of $\mathbf{L}_{6}$ ], 128.6, 128.5 [4 C(III) Ar, C-5, C-5' of bipy], 127.5 [2 C(III) Ar, C-5, C-5' of $\mathbf{L}_{6}$ ] $, 125.3,125.4$ [4 C(III) Ar, C-3, C-3' of 
bipy], 41.2 [2 C(II), $\mathrm{CH}_{2} \mathrm{NHCO}$ ], 32.2 [2 C(II), $\mathrm{CH}_{2} \mathrm{CH}_{2} \mathrm{CH}_{3}$ ], 29.6 [2 C(II), $\mathrm{CH}_{2} \mathrm{CH}_{2} \mathrm{NHCO}$ ], 27.5 [2 C(II), $\mathrm{CH}_{2} \mathrm{CH}_{2} \mathrm{CH}_{2} \mathrm{CH}_{3}$ ], 23.3 [2 C(II), $\mathrm{CH}_{2} \mathrm{CH}_{3}$ ], $14.3\left[2 \mathrm{C}(\mathrm{I}), \mathrm{CH}_{3}\right]$ ppm. MS $\left(\mathrm{ESI}^{+}\right): \mathrm{m} / \mathrm{z}(\%)=412.1(100)[\mathrm{M} / 2]^{2+}$. HRMS $\left(\mathrm{ESI}^{+}\right)$: calcd. for $\mathrm{C}_{44} \mathrm{H}_{50} \mathrm{~N}_{8} \mathrm{O}_{2} \mathrm{Ru}[\mathrm{M} / 2]^{2+}$ 412.1544; found 412.1550

Synthesis and Characterization of $\mathbf{R u}_{\mathbf{7}}$ : Sodium triacetoxyborohydride (155 mg, $8.28 \mathrm{mmol}, 40$ equiv.) and diisopropylamine (9.7 $\mu \mathrm{L}, 0.070 \mathrm{mmol}, 4$ equiv.) were added to a solution of $\mathbf{R} \mathbf{u}_{\mathbf{5}}$ $(25 \mathrm{mg}, 0.0174 \mathrm{mmol})$ in freshly distilled dichloroethane $(2 \mathrm{~mL})$ under an inert atmosphere. After stirring the mixture for $30 \mathrm{~min}$ at room temperature, 2-pyridinecarbaldehyde $(66 \mu \mathrm{L}, 0.70 \mathrm{mmol}$, 40 equiv.) was added. The mixture was stirred for $6 \mathrm{~h}$ at room temperature. Concentration under reduced pressure afforded a red solid, which was washed three times with $30 \mathrm{~mL}$ of pentane and three times with $30 \mathrm{~mL}$ of diethyl ether. After purification by silica gel chromatography (eluent: 80:15:5 $\mathrm{CH}_{3} \mathrm{CN} / \mathrm{H}_{2} \mathrm{O} / \mathrm{KNO}_{3}$ saturated aqueous solution) and elimination of $\mathrm{KNO}_{3}$ by successive precipitation in methanol, the orange product was dissolved in a minimum of distilled water. The dipicolylamine-ruthenium complex was recovered as the hexafluorophosphate salt by precipitation upon the addition of an aqueous saturated solution of ammonium hexafluorophosphate. After filtration, the solid was washed twice with cold distilled water and dried under vacuum. The resulting dipicolylamine-ruthenium complex isolated in $95 \%$ yield $(25 \mathrm{mg}$, $0.0166 \mathrm{mmol}$ ) was dissolved in freshly distilled acetonitrile $(2 \mathrm{~mL})$. Zinc chloride ( $4.52 \mathrm{mg}, 0.0331 \mathrm{mmol}, 2$ equiv.) was added and the mixture stirred at room temperature for $4 \mathrm{~h}$. After elimination of the

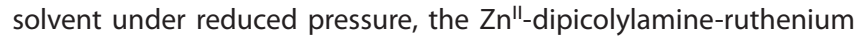
complex $\mathbf{R} \mathbf{u}_{\mathbf{7}}$ was recovered quantitatively $(29.6 \mathrm{mg}, 0.0166 \mathrm{mmol})$ as a red solid. M.p. $182{ }^{\circ} \mathrm{C} .{ }^{1} \mathrm{H}$ NMR $\left(400 \mathrm{MHz}, \mathrm{CD}_{3} \mathrm{CN}, 25^{\circ} \mathrm{C}\right): \delta=$ $8.91(\mathrm{~d}, J=4.8 \mathrm{~Hz}, 4 \mathrm{H}, \mathrm{Py}), 8.50\left(\mathrm{~d}, J=8.2 \mathrm{~Hz}, 4 \mathrm{H} \mathrm{Ar}, 3-\mathrm{H}, 3^{\prime}-\mathrm{H}\right.$ of bipy), 8.14-7.97 (m, $8 \mathrm{H} \mathrm{Ar}, 4-\mathrm{H}, 4^{\prime}-\mathrm{H}$ of bipy, Py), $7.93(\mathrm{~d}, J=8.0 \mathrm{~Hz}$, $2 \mathrm{H} \mathrm{Ar}, 4-\mathrm{H}, 4^{\prime}-\mathrm{H}$ of $\left.\mathbf{L}\right), 7.76\left(\mathrm{~d}, J=4.8 \mathrm{~Hz}, 2 \mathrm{H} \mathrm{Ar}, 6-\mathrm{H}, 6^{\prime}-\mathrm{H}\right.$ of $\left.\mathbf{L}\right)$, $7.66\left(\mathrm{~d}, J=5.2 \mathrm{~Hz}, 2 \mathrm{H} \mathrm{Ar}, 6-\mathrm{H}, 6^{\prime}-\mathrm{H}\right.$ of bipy), 1.22-1.01 (m, $8 \mathrm{H}$, $\mathrm{CH}_{2} \mathrm{CH}_{2} \mathrm{CH}_{2} \mathrm{~N}$ ), $7.52(\mathrm{~d}, J=7.4 \mathrm{~Hz}, 4 \mathrm{H}, \mathrm{Py}), 7.55(\mathrm{t}, J=4.8 \mathrm{~Hz}, 4 \mathrm{H}$, Py), 7.48-7.32 (m, $6 \mathrm{H} \mathrm{Ar}, 5-\mathrm{H}, 5^{\prime}-\mathrm{H}$ of $\mathbf{L}$ and bipy), 7.25 (s, $\left.2 \mathrm{H}, \mathrm{NH}\right)$, $4.14\left(\mathrm{~s}, 8 \mathrm{H}, \mathrm{CH}_{2}-\mathrm{Py}\right), 3.30-2.90\left(2 \mathrm{~m}, 4 \mathrm{H}, \mathrm{CH}_{2} \mathrm{NHCO}\right.$, cis/trans isomers), $2.72-2.55\left(\mathrm{~m}, 4 \mathrm{H}, \mathrm{CH}_{2} \mathrm{~N}\right), 1.47-1.30\left(\mathrm{~m}, 8 \mathrm{H}, \mathrm{CH}_{2} \mathrm{CH}_{2} \mathrm{~N}\right), 1.25-$ $0.95\left(\mathrm{~m}, 8 \mathrm{H}, \mathrm{CH}_{2}\right)$ ppm. ${ }^{13} \mathrm{C}$ NMR $\left(100 \mathrm{MHz}, \mathrm{CD}_{3} \mathrm{CN}, 25^{\circ} \mathrm{C}\right): \delta=$ 165.5 [2 C(IV), CONH], 158.0, 157.8 [6 C(IV) Ar, C-2, C-2' of bipy, L], 156.2 [4 C(III), Py], 152.8 [4 C(IV) Ar, C-6, C-6' of bipy, L], 149.3 [4 C(III), Py], 141.9 [4 C(III), Py], 139.1, 139.0, 137.9 [6 C(III) Ar, C-4, C-4' of bipy, L], 139.0 [2 C(IV) Ar, C-3, C-3' of L], 128.7, 128.6 [4 C(III) Ar, C-5, C-5' of bipy], 127.6 [2 C(III) Ar, C-5, C-5' of L], 125.7 [4 C(III), Py], 125.4, 125.3 [4 C(III) Ar, C-3, C-3' of bipy], 125.2 [4 C(III), Py], 58.0 [4 $\left.\mathrm{C}(\mathrm{II}), \mathrm{CH}_{2} \mathrm{Py}\right], 56.0$ [2 C(II), $\mathrm{CH}_{2} \mathrm{~N}$ ], 40.9 [2 C(II), $\mathrm{CH}_{2} \mathrm{NHCO}$, 29.3 [2 $\left.\mathrm{C}(\mathrm{II}), \mathrm{CH}_{2} \mathrm{CH}_{2} \mathrm{NH}\right], 27.4,27.1\left[4 \mathrm{C}(\mathrm{II}), \mathrm{CH}_{2} \mathrm{CH}_{2} \mathrm{CH}_{2} \mathrm{~N}\right], 24.8$ [2 $\mathrm{C}(\mathrm{II})$, $\left.\mathrm{CH}_{2} \mathrm{CH}_{2} \mathrm{~N}\right]$ ppm. HRMS $\left(\mathrm{ESI}^{+}\right)$: calcd. for $\mathrm{C}_{68} \mathrm{H}_{72} \mathrm{~N}_{14} \mathrm{O}_{2}{ }^{35} \mathrm{Cl}_{4}{ }^{64} \mathrm{Zn}_{2}{ }^{102} \mathrm{Ru}$ $[\mathrm{M} / 2]^{2+} 743.1166$; found 743.1168 .

\section{Acknowledgments}

The authors thank the Centre National de la Recherche Scientifique (CNRS) and the Region Aquitaine for financial support.

Keywords: Molecular recognition - Luminescence ·

Ruthenium · Glutamate · Nucleotides

[1] a) F. Lang, M. Föller, Channels 2014, 8, 20-28; b) P. J. Kilfoil, S. M. Tipparaju, O. A. Barski, A. Bhatnagar, Circ. Res. 2013, 112, 721-741.

[2] a) T. Pawson, J. D. Scott, Trends Biochem. Sci. 2005, 30, 286-290; b) T. Hunter, Protein Phosphorylation, Academic Press, New York, 1998.
[3] L. N. Johnson, R. J. Lewis, Chem. Rev. 2001, 101, 2209-2242.

[4] a) N. H. Evans, P. D. Beer, Angew. Chem. Int. Ed. 2014, 53, 11716-11754; Angew. Chem. 2014, 126, 11908; b) A. E. Hargrove, S. Nieto, T. Zhang, J. L. Sessler, E. V. Anslyn, Chem. Rev. 2011, 111, 6603-6782; c) R. M. Duke, E. B. Veale, F. M. Pfeffer, P. E. Kruger, T. Gunnlaugsson, Chem. Soc. Rev. 2010, 39, 3936-3953; d) P. Beer, S. Bayly in Anion Sensing Vol. 255 (Ed.: I. Stibor), Springer, Berlin, Heidelberg, 2005, pp. 125-162; e) P. D. Beer, E. J. Hayes, Coord. Chem. Rev. 2003, 240, 167-189; f) P. D. Beer, P. A. Gale, Angew. Chem. Int. Ed. 2001, 40, 486-516; Angew. Chem. 2001, 113, 502; g) B. Chowdhury, R. Dutta, S. Khatua, P. Ghosh, Inorg. Chem. 2016, 55, 259271.

[5] a) L. M. Mesquita, V. André, C. V. Esteves, T. Palmeira, M. N. BerberanSantos, P. Mateus, R. Delgado, Inorg. Chem. 2016, 55, 2212-2219; b) H. R. Xu, K. Li, M. Q. Wang, B. L. Wang, X. Wang, X. Q. Yu, Org. Chem. Front. 2014, 1, 1276-1279; c) B. K. Datta, S. Mukherjee, C. Kar, A. Ramesh, G. Das, Anal. Chem. 2013, 85, 8369-8375; d) L. G. Pathberiya, N. Barlow, T. Nguyen, B. Graham, K. L. Tuck, Tetrahedron 2012, 68, 9435-9439; e) H. T. Ngo, X. Liu, K. A. Jolliffe, Chem. Soc. Rev. 2012, 41, 4928-4965; f) I. Ravikumar, P. Ghosh, Inorg. Chem. 2011, 50, 4229-4231.

[6] a) S. Anbu, R. Ravishankaran, M. F. C. Guedes da Silva, A. A. Karande, A. J. L. Pombeiro, Inorg. Chem. 2014, 53, 6655-6664; b) W. Zhu, X. Huang, Z. Guo, X. Wu, H. Yu, H. Tian, Chem. Commun. 2012, 48, 1784-1786; c) X. Feng, Y. An, Z. Yao, C. Li, G. Shi, ACS Appl. Mater. Interfaces 2012, 4, 614618.

[7] A. K. Mahapatra, S. S. Ali, K. Maiti, S. K. Manna, R. Maji, S. Mondal, M. R. Uddin, S. Mandal, P. Sahoo, RSC Adv. 2015, 5, 81203-81211.

[8] a) C. Patra, A. K. Bhanja, A. Mahapatra, S. Mishra, K. D. Saha, C. Sinha, RSC Adv. 2016, 6, 76505-76513; b) L. Wang, L. Yuan, X. Zeng, J. Peng, Y. Ni, J. C. Er, W. Xu, B. K. Agrawalla, D. Su, B. Kim, Y.-T. Chang, Angew. Chem. Int. Ed. 2016, 55, 1773-1776; Angew. Chem. 2016, 128, 1805-1808; c) A. K. Gupta, A. Dhir, C. P. Pradeep, Eur. J. Org. Chem. 2015, 122-129; d) F. Shi, Y. Li, Z. Lin, D. Ma, X. Su, Sens. Actuators B 2015, 220, 433-440; e) L. Xiao, S. Sun, Z. Pei, Y. Pei, Y. Pang, Y. Xu, Biosens. Bioelectron. 2015, 65, 166-170; f) S. J. Butler, Chem. Eur. J. 2014, 20, 15768-15774; g) J. L. Tang, C. Y. Li, Y. F. Li, C. X. Zou, Chem. Commun. 2014, 50, 15411-15414; h) Q.-c. Xu, H.-j. Lv, Z.-q. Lv, M. Liu, Y.-j. Li, X.-f. Wang, Y. Zhang, G.-w. Xing, RSC Adv. 2014, 4, 47788-47792; i) S. Nadella, P. M. Selvakumar, E. Suresh, P. S. Subramanian, M. Albrecht, M. Giese, R. Froehlich, Chem. Eur. J. 2012, 18, 16784-16792; j) X.-B. Zhou, W.-H. Chan, A. W. M. Lee, Tetrahedron Lett. 2011, 52, 5431-5434; k) X.-J. Zhao, C.-Z. Huang, TrAC Trends Anal. Chem. 2010, 29, 354-367; I) E. A. Weitz, J. Y. Chang, A. H. Rosenfield, V. C. Pierre, J. Am. Chem. Soc. 2012, 134, 16099-16102.

[9] a) J. Sahoo, R. Arunachalam, P. S. Subramanian, E. Suresh, A. Valkonen, K. Rissanen, M. Albrecht, Angew. Chem. Int. Ed. 2016, 55, 9625-9629; Angew. Chem. 2016, 128, 9777-9781; b) W. Xu, Y. Zhou, D. Huang, M. Su, K. Wang, M. Xiang, M. Hong, J. Mater. Chem. C 2015, 3, 2003-2015; c) A. Kumar, P. Prasher, P. Singh, Org. Biomol. Chem. 2014, 12, 3071-3079; d) L. Shi, P. Hu, Y. Ren, G. Feng, Chem. Commun. 2013, 49, 11704-11706; e) X.-F. Shang, H. Su, H. Lin, H.-K. Lin, Inorg. Chem. Commun. 2010, 13, 999-1003; f) S. Kunzelmann, M. R. Webb, ACS Chem. Biol. 2010, 5, 415425; g) M. Cano, L. Rodriguez, J. C. Lima, F. Pina, A. Dalla Cort, C. Pasquini, L. Schiaffino, Inorg. Chem. 2009, 48, 6229-6235; h) S. Kunzelmann, M. R. Webb, J. Biol. Chem. 2009, 284, 33130-33138; i) J. Srinivasan, S. T. Cload, N. Hamaguchi, J. Kurz, S. Keene, M. Kurz, R. M. Boomer, J. Blanchard, D. Epstein, C. Wilson, J. L. Diener, Chem. Biol. 2004, 11, 499-508; j) M. Brune, J. E. T. Corrie, M. R. Webb, Biochemistry 2001, 40, 5087-5094; k) D. Wang, X. Zhang, C. He, C. Duan, Org. Biomol. Chem. 2010, 8, 2923-2925.

[10] A. Juris, V. Balzani, F. Barigelletti, S. Campagna, P. Belser, A. von Zelewsky, Coord. Chem. Rev. 1988, 84, 85-277.

[11] a) V. P. Boricha, S. Patra, S. Parihar, Y. S. Chouhan, P. Paul, Polyhedron 2012, 43, 104-113; b) H. Khanmohammadi, K. Rezaeian, New J. Chem. 2014, 38, 5536-5543; c) D. Saha, S. Das, S. Karmakar, S. Dutta, S. Baitalik, RSC Adv. 2013, 3, 17314-17334; d) X. Shang, X. Li, N. Xi, Y. Zhai, J. Zhang, X. Xu, Sens. Actuators B 2011, 160, 1112-1119; e) A. Chakraborty, R. Gunupuru, D. Maity, S. Patra, E. Suresh, P. Paul, Inorg. Chem. Commun. 2010, 13, 1522-1526; f) H.-X. Yang, Y.-J. Liu, L. Zhao, K.-Z. Wang, Spectrochim. Acta Part A 2010, 76A, 146-149.

[12] E. Berni, I. Gosse, D. Badocco, P. Pastore, N. Sojic, S. Pinet, Chem. Eur. J. 2009, 15, 5145-5152. 
[13] S. L. Wiskur, J. J. Lavigne, A. Metzger, S. L. Tobey, V. Lynch, E. V. Anslyn, Chem. Eur. J. 2004, 10, 3792-3804.

[14] B. Z. Shan, Q. Zhao, N. Goswami, D. M. Eichhorn, D. P. Rillema, Coord. Chem. Rev. 2001, 211, 117-144.

[15] P. D. Beer, N. C. Fletcher, T. Wear, Polyhedron 1996, 15, 1339-1347.

[16] M. S. Vickers, K. S. Martindale, P. D. Beer, J. Mater. Chem. 2005, 15, 27842790.

[17] P. D. Beer, F. Szemes, V. Balzani, C. M. Salà, M. G. B. Drew, S. W. Dent, M. Maestri, J. Am. Chem. Soc. 1997, 119, 11864-11875.

[18] J. A. Treadway, B. Loeb, R. Lopez, P. A. Anderson, F. R. Keene, T. J. Meyer, Inorg. Chem. 1996, 35, 2242-2246.
[19] J. V. Caspar, T. J. Meyer, J. Am. Chem. Soc. 1983, 105, 5583-5590.

[20] M. D. Pratt, P. D. Beer, Tetrahedron 2004, 60, 11227-11238.

[21] a) P. Gans, A. Sabatini, A. Vacca, Talanta 1996, 43, 1739-1753; b) P. Gans, A. Sabatini, A. Vacca, Ann. Chim. 1999, 89, 45-49.

[22] C. R. Allen, P. L. Richard, A. J. Ward, L. G. A. van de Water, A. F. Masters, T. Maschmeyer, Tetrahedron Lett. 2006, 47, 7367-7370.

[23] M. Carmignani, A. R. Volpe, B. Botta, R. Espinal, S. C. De Bonnevaux, C. De Luca, M. Botta, F. Corelli, A. Tafi, R. Sacco, G. Delle Monache, J. Med. Chem. 2001, 44, 2950-2958. 